Article

\title{
Uptake and Effects of Cylindrospermopsin: Biochemical, Physiological and Biometric Responses in The Submerged Macrophyte Egeria densa Planch
}

\author{
Nelida Cecilia Flores-Rojas ${ }^{1}$ and Maranda Esterhuizen $2,3,4, *$ (D) \\ 1 Technische Universität Berlin, Institute of Ecology, Ernst-Reuter-Platz 1, 10587 Berlin, Germany; \\ nceci33@yahoo.com \\ 2 Ecosystems and Environmental Research Programme, Faculty of Biological and Environmental Sciences, \\ University of Helsinki, Niemenkatu 73, 15140 Lahti, Finland \\ 3 Joint Laboratory of Applied Ecotoxicology, Korea Institute of Science and Technology Europe (KIST Europe), \\ Campus 7.1, 66123 Saarbrücken, Germany \\ 4 Helsinki Institute of Sustainability Science (HELSUS), University of Helsinki, Fabianinkatu 33, \\ 00014 Helsinki, Finland \\ * Correspondence: maranda.esterhuizen@helsinki.fi; Tel.: +358-50-318-8337
}

Received: 21 September 2020; Accepted: 22 October 2020; Published: 26 October 2020

\begin{abstract}
Cylindrospermopsin (CYN) is being detected in surface waters more commonly and frequently worldwide. This stable, extracellular cyanotoxin causes protein synthesis inhibition, thus posing a risk to aquatic biota, including macrophytes, which serve as primary producers. Nevertheless, data regarding the effects caused by environmental concentrations of CYN is still limited. In the presented study, the uptake of CYN at environmental concentrations by the submerged macrophyte Egeria densa was investigated. Bioaccumulation, changes in the plant biomass, as well as shoot-length were assessed as responses. Variations in the cellular $\mathrm{H}_{2} \mathrm{O}_{2}$ levels, antioxidative enzyme activities, as well as concentrations and ratios of the photosynthetic pigments were also measured. E. densa removed $54 \%$ of CYN within $24 \mathrm{~h}$ and up to $68 \%$ after $336 \mathrm{~h}$; however, CYN was not bioaccumulated. The antioxidative enzyme system was activated by CYN exposure. Pigment concentrations decreased with exposure but normalized after $168 \mathrm{~h}$. The chlorophyll $a$ to $b$ ratio increased but normalized quickly thereafter. Carotenoids and the ratio of carotenoids to total chlorophylls increased after $96 \mathrm{~h}$ suggesting participation in the antioxidative system. Growth stimulation was observed. The ability to remove CYN and resistance to CYN toxicity within 14 days proved E. densa as suitable for phytoremediation; nonetheless, prolonged exposure (32 days) resulted in adverse effects related to CYN uptake, which needs to be studied further.
\end{abstract}

Keywords: cylindrospermopsin; Egeria densa; uptake; oxidative stress; pigment contents; phytoremediation

\section{Introduction}

The cyanobacterial toxin cylindrospermopsin (CYN) has been recognized as an environmental hazard and has been detected in surface waters globally [1]. To date, known species of CYN producing cyanobacteria belonging to Nostocales and Oscillatoriales, specifically Cylindrospermopsis raciborskii, Raphidiopsis curvata, Aphanizomenon flos-aquae, Anabaena spp., Umezakia natans, and Lyngbya spp. [2]. CYN concentrations of up to $92 \mu \mathrm{g} / \mathrm{L}$ have been reported in surface waters containing a bloom, which far exceed the guideline value of $1 \mu \mathrm{g} / \mathrm{L}$ for safe consumption [1]. Considering the widespread distribution of CYN producers and the ever-increasing frequency of occurrence and prolonged blooms of CYN producing cyanobacteria, the toxin poses a likely risk to both humans and the balance of aquatic ecosystems [1,3]. Risks to human health may be presented when 
cyanobacterial harmful algal blooms occur in drinking and recreational water sources [1] or consuming toxin-laden tissues [3]. CYN is an alkaloid with zwitterionic properties comprising of one tricyclic guanidine attached to a hydroxymethyluracil [4], with two natural structural variants currently known: 7-epi-cylindrospermopsin (7-epi-CYN) and 7-deoxycylindrospermopsin (7-deoxy-CYN) [5,6]. De la Cruz et al. [1] showed the structure of CYN and its variants as seen below (Figure 1):<smiles>C[C@@H]1[C@@H](OS(=O)(=O)[O-])C[C@H]2CC[C@H]([C@H](O)c3cc(=O)[nH]c(=O)[nH]3)[C@@H]3C(=[NH+]C[C@H]13)N2</smiles>

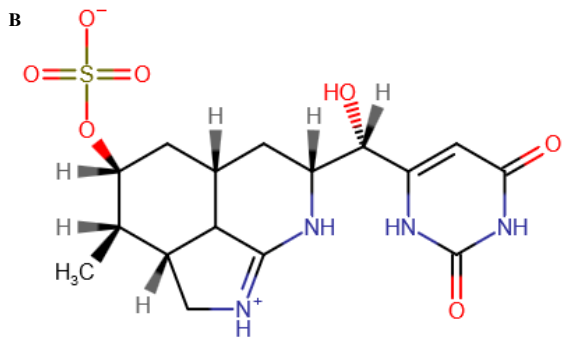

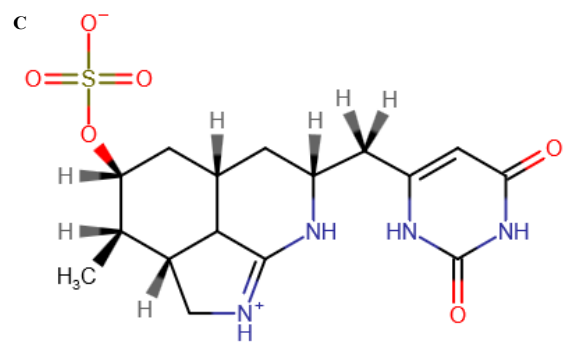

Figure 1. (A) Structure of cylindrospermopsin (CYN) and its analogues: (B) 7-epi-cylindrospermopsin (7-epi-CYN) and (C) 7-deoxycylindrospermopsin (7-deoxy-CYN). Redrawn from De la Cruz et al. [1] using Chemspace (2018).

CYN is highly water-soluble due to the hydroxymethyluracil [7]; is stable under a varied range of light, heat, and $\mathrm{pH}$ conditions [8]; and is often present in surface waters extracellularly [9]. Together with its capability to covalent bind to DNA/RNA [10] and hinder protein synthesis, CYN could potentially affect countless aquatic plant and animal species [3,8]. Studies focusing on CYN uptake by aquatic plants, biochemical and physiological changes, or consequences on growth linked to CYN exposure are scarce. Due to the role of macrophytes as the primary producers in oligotrophic ecosystems supporting the dependent higher trophic levels [11] and their participation in nutrient cycling control, it is pertinent to investigate the effects of CYN on macrophytes to understand the comprehensive effect on the ecosystem.

Some studies investigating the adaptation of CYN in aquatic plants have reported negligible uptake related to low bioconcentration factors $(\mathrm{BCF})$ after exposures to high CYN concentrations, far exceeding those recorded in nature [12-14]. For Hydrilla verticillata (BFC 0.045), White et al. [12] reported $15 \mathrm{ng}$ CYN/g fresh weight (FW) after seven days of exposure to $400 \mu \mathrm{g} / \mathrm{LCYN}$. Landoltia punctata (Spirodella oligorrhyza previously) exposed to crude extracts of $C$. raciborskii contained $30 \mathrm{ng}$ CYN/g FW plant biomass after six days of exposure to up to $500 \mu \mathrm{g} / \mathrm{L} \mathrm{CYN} \mathrm{[13].} \mathrm{In} \mathrm{Azolla} \mathrm{filiculoides,} \mathrm{exposed} \mathrm{to}$ 
crude cyanobacterial extracts containing 50,500, and $5000 \mu \mathrm{g} / \mathrm{L}$ CYN for seven days, $1.31 \pm 0.11 \mu \mathrm{g}$ $\mathrm{CYN} / \mathrm{g}$ plant material $\mathrm{FW}$ was taken up resulting in a BCF of $0.40 \pm 0.04$, which could be quantifiable in the macrophytes exposed to the maximum CYN concentration exclusively [14]. A recent study with L. minor exposed to $25 \mu \mathrm{g} / \mathrm{L}$ of pure CYN for $168 \mathrm{~h}$ [15], reported the detection of free CYN in the plant tissues ranging from $0.82 \pm 0.03 \mathrm{ng}$ CYN/g FW to $0.85 \pm 0.01 \mathrm{ng} \mathrm{CYN/g} \mathrm{FW} \mathrm{and} \mathrm{highest} \mathrm{BCF} \mathrm{calculated}$ was $0.095 \pm 0.03$ after $24 \mathrm{~h}$. The same study also found that soluble CYN in the exposed plant biomass represented only up to $0.30 \%$ of CYN removed from the surroundings.

Some studies on plants exposed to CYN have reported oxidative stress promotion, i.e., the increase of glutathione peroxidase (GPx) and glutathione S-transferase (GST) activities to counteract reactive oxygen species (ROS). Rice plants (Oryza sativa) exposed to $2.5 \mu \mathrm{g} / \mathrm{L}$ CYN showed increased GST and GPx enzyme activities in the plant roots and leaves after nine days [16]. In A. filiculoides exposed to $5 \mu \mathrm{g} / \mathrm{L}$ CYN, the GST activity also increased after seven days [14]. Common lettuce Lactuca sativa [17] exposed to $1 \mu \mathrm{g} / \mathrm{L}, 10 \mu \mathrm{g} / \mathrm{L}$, and $100 \mu \mathrm{g} / \mathrm{L}$ CYN mainly showed increases in the GST and GPx activities in roots at all exposure concentrations after five days and ten days. In L. minor exposed to CYN, the catalase (CAT) activity increased with exposure to 2.5 and $25 \mu \mathrm{g} / \mathrm{L} \mathrm{CYN}$ within $168 \mathrm{~h}$ [18]. In the same study, the enzyme activities of GST and glutathione reductase (GR) amplified after $24 \mathrm{~h}$ exposure with $25 \mu \mathrm{g} / \mathrm{L}$ CYN. After $168 \mathrm{~h}$, the activities peaked only at the highest CYN concentration [18]. Presumably, CAT acts as the initial protective response in controlling oxidative stress, followed by the activation of GST and GR during longer exposures to greater CYN concentrations.

On the subject of plant growth alterations, the results in previous studies vary and seem to depend on the CYN concentration, which could inhibit or stimulate growth. For A. filiculoides, an aquatic fern, growth was inhibited by $99.8 \%$ after seven days of exposure to $5000 \mu \mathrm{g} / \mathrm{L}$ CYN; while it grew unaltered at lower concentrations [14]. The authors also reported increases in the photosynthetic pigment concentrations as well as protein contents. For L. minor and Wolffia arrhiza exposure to both a natural cyanobacterial fraction as well as CYN as a single pure toxin (concentrations from 10 to $20,000 \mu \mathrm{g} / \mathrm{L}$ ) caused growth alterations, comprising decreased frond numbers and biomass after five days [19]. Root growth stimulus in $H$. verticillata exposed to $400 \mu \mathrm{g} / \mathrm{L} \mathrm{CYN} \mathrm{[20],} \mathrm{increased} \mathrm{biomass} \mathrm{in}$ Landoltia punctata exposed to $117 \mathrm{~g} / \mathrm{L}$ CYN [13] and reduced fresh weight of leaves in O. sativa exposed to $2.5 \mu \mathrm{g} / \mathrm{L}$ CYN [16] have also been linked to CYN exposure regardless of purified toxin or crude extract exposure.

Research regarding the environmental implications of CYN exposure in aquatic environments has increased $[1,3,7,10]$; however, the uptake, subsequent effects on a physiological and morphological scale in macrophytes exposed to CYN at concentrations detected in the environment have not been studied comprehensively. Such studies will allow a better understanding of the environmental fate of CYN and the responses of plants' defense mechanisms, to further evaluate their fitness for phytoremediation [21] and to achieve a comprehensive understanding of how the ecosystem is affected by CYN.

The submerged macrophyte Egeria densa native from South America is widely distributed around the world [22]. It was selected for this study due to its favorable characteristics, including rapid growth and abundance in nature. The current study investigated the macrophyte's ability to assimilate CYN and the corresponding biochemical reactions in response to pure CYN uptake. The variations in the antioxidative enzyme activities, the pigment and carotenoids, in addition to the biomass and shoot length served as gauges of $E$. densa's physiological status as a function of interaction with CYN. Thus, the study indirectly evaluated the fitness of the macrophyte for use in phytoremediation or as bio-indicator to assess the environmental impact of $\mathrm{CYN}$ in aquatic environments.

\section{Materials and Methods}

\subsection{Plant Material}

E. densa shoots were provided by Extraplant (Extra-group GmbH, Münster, Germany). The macrophyte E. densa was cultured in modified Provasoli's medium according to Flores-Rojas et al. [15] 
in pre-cultivated glass tanks $(60 \mathrm{~cm} \times 30 \mathrm{~cm} \times 30 \mathrm{~cm})$ at $25 \pm 1^{\circ} \mathrm{C}$ under a day to night cycle of $14 \mathrm{~h} \mathrm{light}$ to $10 \mathrm{~h}$ darkness using under cool, white fluorescent light at an irradiance of $38 \mathrm{E} / \mathrm{m}^{2} / \mathrm{s}$ [23]. The same cultivation parameters were applied during the treatments. The plants were pre-acclimated in the exposure containers for seven days prior to the start of the study.

\subsection{Chemicals}

CYN (purify $>95 \%$ ) was acquired from Alexis Biochemicals (Lausen, Switzerland) as a pure toxin in powder form, and a stock solution was prepared in $70 \%$ methanol. All chemicals were analytical grade and acquired from Sigma-Aldrich, Inc. (Darmstadt, Germany) unless stated otherwise.

\subsection{Experimental Design}

CYN was diluted in the Provasoli's medium to four final exposure concentrations $(0.025,0.25,2.5$, and $25 \mu \mathrm{g} / \mathrm{L}$ ). These concentrations were based on CYN concentrations previously detected in aquatic environments $[1,24,25]$. All experiments were conducted with non-axenic plants under non-sterile conditions. Per exposure treatment, E. densa shoots amounting to a total FW of $3.5 \pm 0.5 \mathrm{~g}$ were individually subjected to each of the four specified CYN concentrations $(150 \mathrm{~mL})$ under the controlled culture conditions described above for a period of $336 \mathrm{~h}$. The treatments were set up in parallel with their corresponding negative controls, which consisted of the exposure medium without CYN in replicates of four.

Due to the limit of quantification (10 pg on column; see Section 2.4) of the quantitative method, the uptake of CYN with time could only be studied with the highest exposure concentration $(25 \mu \mathrm{g} / \mathrm{L} \mathrm{CYN})$. From the treatment and control sets, samples were collected after specific time points $(4,8,24,48,96$, 168 , and $336 \mathrm{~h}$ ) to quantify the CYN remaining in the media employing liquid chromatography-tandem mass spectrometry (LC-MS/MS; Section 2.4). As a means to assess the spontaneous CYN degradation, an additional positive control, which consisted of $25 \mu \mathrm{g} / \mathrm{L} \mathrm{CYN} \mathrm{medium} \mathrm{lacking} \mathrm{plants,}(n=4)$ was run in parallel.

The set-up was duplicated in order to assess the cellular $\mathrm{H}_{2} \mathrm{O}_{2}$ concentration and the enzymatic activity after $24 \mathrm{~h}$, with all four exposure concentrations and after 4, 8, 48, 96, 168, and $336 \mathrm{~h}$ with concentrations of $2.5 \mu \mathrm{g} / \mathrm{L}$ and $25 \mu \mathrm{g} / \mathrm{L} \mathrm{CYN}(n=5)$. The analyses of the $\mathrm{H}_{2} \mathrm{O}_{2}$ level and antioxidative stress enzyme activities were accomplished as described in Sections 2.5 and 2.6, respectively. The photosynthetic pigment contents were measured after $24 \mathrm{~h}$ with exposure of E. densa to all four CYN concentrations and after 48, 96, 168, and $336 \mathrm{~h}$ with $2.5 \mu \mathrm{g} / \mathrm{L}$ and $25 \mu \mathrm{g} / \mathrm{L} \mathrm{CYN}$ $(n=5)$ as described in Section 2.7. Following exposure, the plants were rinsed with water (de-ionized) twice to eliminate any externally adhering toxin. The samples were shock-frozen and stored $\left(-80{ }^{\circ} \mathrm{C}\right)$ until further analysis. Plant growth experiment was carried out with all four CYN concentrations for 32 days. Growth parameters were measured and analyzed, as described in Section 2.8.

\subsection{Analysis of CYN}

Soluble CYN was isolated from the plant biomass as described by Esterhuizen-Londt et al. [26] with minor modifications. The frozen plant samples were powdered while frozen and lyophilized (LIO-5P freeze-dryer Kambič Laboratorijska oprema doo, Semič, Slovenija) for $18 \mathrm{~h}\left(-50.3^{\circ} \mathrm{C}\right.$; $6.1 \mathrm{mbar})$. The freeze-dried samples $(500 \mathrm{mg})$ were further processed utilizing a Tissuelyser LT (Qiagen, Hilden, Germany), then dissolved in 95\% acetonitrile (ACN), and treated for half an hour in an ultrasonic water bath (Alpax, Gmbh \& Co. KG). Using an overhead Intelli-Mixer RM-2 (Neolab, Heidelberg, Germany), the samples were mixed for half an hour at ambient temperature in darkness, and after that centrifugation $\left(20,800 \times g, 15 \mathrm{~min}, 4^{\circ} \mathrm{C}\right.$; Eppendorf Centrifuge $5417 \mathrm{R}, \mathrm{Hamburg}$, Germany). ACN (95\%) was used to resuspend the resulting pellets, which were again centrifuged. The CYN in the pooled extracts, as well as the exposure media, were quantified via LC-MS/MS.

Matrix partition was accomplished on a Kinetex HILIC column $(2.6 \mu \mathrm{m}, 2.1 \times 100 \mathrm{~mm})$ via liquid chromatography (1200 infinity Series, Agilent, Waldbronn, Germany) coupled to triple quadrupole 
mass spectrometry (model 6460 Triple $\mathrm{Q}^{\mathrm{TM}}$, Agilent, Waldbronn, Germany) with electrospray ionization (Jet-Stream, Agilent) as shown by Esterhuizen-Londt et al. [26]. The temperature of the column heater was $35^{\circ} \mathrm{C}$. A sample volume of $10 \mu \mathrm{L}$ was injected, which was analyzed on the system at a flow rate of $0.5 \mathrm{~mL} / \mathrm{min}$. A gradient was used to separate the matrix, starting with $95 \%$ ACN (MS grade) for $3 \mathrm{~min}$, which decreased to $50 \%$ for $4 \mathrm{~min}$ and re-equilibrated for $3 \mathrm{~min}$. Using this program, CYN had a retention time of $4.1 \mathrm{~min}$. The MS-MS parameters were set up using MRM mode (positive mode) with a mass transfer of 416 (Q1) to 176 and 194 (Q3) for CYN. The drying gas temperature and flow were $320^{\circ} \mathrm{C}$ and $12 \mathrm{~L} / \mathrm{min}$, respectively, and the sheath gas temperature and flow were $380{ }^{\circ} \mathrm{C}$ and $12 \mathrm{~L} / \mathrm{min}$ using nitrogen gas. The capillary and nozzle voltage was $4500 \mathrm{~V}$ and $1200 \mathrm{~V}$, respectively, with a 25 psi nebulizer pressure. The plots used for calibration were linear $\left(R^{2}=0.998\right)$ between 0.01 and $100 \mu \mathrm{g} / \mathrm{L}$. The limit of quantification was set at $10 \mathrm{pg}$ on column $(\mathrm{S} / \mathrm{N} \geq 5)$.

CYN concentrations in exposure media and free CYN in plant tissue quantified via LC-MS/MS were used to calculate the BCFs, according to Equation (1) [27] as:

$$
\mathrm{BCF}=\mathrm{C}_{\mathrm{B}} / \mathrm{C}_{\mathrm{WD}}
$$

where $C_{B}$ is the chemical concentration in the organism $(n g / g)$ and $C_{W D}$ is the freely dissolved chemical concentration in the water $(\mathrm{ng} / \mathrm{mL})$.

\subsection{Hydrogen Peroxide $\left(\mathrm{H}_{2} \mathrm{O}_{2}\right)$ Determination}

Cellular $\mathrm{H}_{2} \mathrm{O}_{2}$ was determined colorimetrically following the methods of Jana and Choudhuri [28]. First, $0.3 \mathrm{~g}$ FW of macerated plant biomass was mixed with $3 \mathrm{~mL}$ of $50 \mathrm{mM} \mathrm{pH} 7$ sodium phosphate buffer, following a centrifugation step $\left(20,800 \times g, 15 \mathrm{~min}, 4^{\circ} \mathrm{C}\right)$. The supernatant $(750 \mu \mathrm{L})$ was combined with $250 \mu \mathrm{L}$ of $0.1 \%$ titanium chloride in $20 \% \mathrm{H}_{2} \mathrm{SO}_{4}(\mathrm{v} / \mathrm{v})$. Following a short incubation at ambient temperature, the absorption was measured photometrically at $410 \mathrm{~nm}$ (extinction coefficient $\varepsilon=0.28 \mathrm{~L} / \mathrm{mmol} \cdot \mathrm{cm}$ ) and expressed as $\mu \mathrm{mol} / \mathrm{g}$ FW.

\subsection{Enzyme Extraction and Activity Measurement}

The enzyme preparation was completed following the procedure published by Pflugmacher [29]. The frozen plant material (1.5 g FW) was macerated in liquid nitrogen. The powder was suspended in $0.1 \mathrm{M}$ sodium phosphate buffer ( $\mathrm{pH}$ 6.5) containing $20 \%$ glycerol, $1 \mathrm{mM}$ ethylenediaminetetraacetic acid (EDTA), and $1.4 \mathrm{mM}$ dithioerythritol (DTE). Cellular remains were removed by centrifugation at $10,600 \times g$ for $10 \mathrm{~min}$ at $4{ }^{\circ} \mathrm{C}$ (Eppendorf Centrifuge $5417 \mathrm{R}$, Hamburg, Germany). Dissolved proteins were precipitated by ammonium sulfate at $80 \%$ saturation, followed by centrifugation $(20,800 \times g, 60 \mathrm{~min}$, $4{ }^{\circ} \mathrm{C}$ ). The resultant pellet was liquefied in $20 \mathrm{mM}$ sodium phosphate buffer ( $\mathrm{pH} 7.0$ ) and purified using Sephadex G-25 columns (NAP-columns, Amersham GE Healthcare, Uppsala, Sweden). The protein concentration was quantified at $595 \mathrm{~nm}$ after applying Bradford reagent [30]. The protein extracts were kept at $-80{ }^{\circ} \mathrm{C}$ until further processing.

CAT (EC 1.11.1.6) enzyme activity was evaluated as described by Claiborne [31], which assesses the decrease of $\mathrm{H}_{2} \mathrm{O}_{2}$ as a decreased absorption at $240 \mathrm{~nm}(\varepsilon=0.0361 \mathrm{~L} / \mathrm{mmol} \cdot \mathrm{cm})$. Peroxidase (POD; EC 1.11.1.7) was measured as outlined by Pütter [32]. The substrate guaiacol was reduced by $\mathrm{H}_{2} \mathrm{O}_{2}$ to octahydrotetraguaiacol, which was measured at $436 \mathrm{~nm}(\varepsilon=25.5 \mathrm{~L} / \mathrm{mmol} \cdot \mathrm{cm})$. The activity of GST (EC 2.5.1.18) was assessed by measuring the conjugation of 1-chloro-2,4-dinitrobenzene (CDNB) with glutathione (GSH) at $340 \mathrm{~nm}$ (extinction coefficient $\varepsilon=9,6 \mathrm{~L} / \mathrm{mmol} \cdot \mathrm{cm}$ ) as shown by Habig et al. [33]. GR (EC 1.6.4.2) activity was determined by observing the rate of nicotinamide adenine dinucleotide phosphate (NADPH) oxidation, dependent on the reduction of glutathione disulfide (GSSG) at $340 \mathrm{~nm}$ $(\varepsilon=6.4 \mathrm{~L} / \mathrm{mmol} \cdot \mathrm{cm})$ as described by Carlberg and Mannervik [34]. 


\subsection{Photosynthetic Pigment Contents}

The chlorophyll concentration was measured according to Inskeep and Bloom [35] and the carotenoid contents according to Wellburn [36]. The frozen E. densa biomass was powdered in liquid nitrogen. From this powder, $0.1 \mathrm{~g} \mathrm{FW}$ was dissolved in $5 \mathrm{~mL}$ of $\mathrm{N}, \mathrm{N}$-dimethylformamide (N,N-DMF) and kept at $4{ }^{\circ} \mathrm{C}$ in complete darkness for three days, followed by centrifugation (Eppendorf Centrifuge $5417 \mathrm{R}$, Hamburg, Germany) at 20,800 $\mathrm{g}\left(15 \mathrm{~min}\right.$ at $\left.4{ }^{\circ} \mathrm{C}\right)$. Quantification was performed spectrophotometrically at $647 \mathrm{~nm}, 664.5 \mathrm{~nm}$ (for chlorophyll a and b respectively), and $480 \mathrm{~nm}$ (for carotenoids) using cuvettes made of quartz. The chlorophyll $a$ to $b$ ratio $(\mathrm{chl} a / b)$, a bioindicator of cellular stress and effects on photosynthesis [37], was calculated by dividing the concentration of chlorophyll $a$ by the concentration of chlorophyll $b$.

\subsection{Plant Growth Parameters}

E. densa shoots containing the apical meristems were exposed to all four concentrations of CYN in a volume of $150 \mathrm{~mL}$ for 32 days. Shoots were $9 \pm 2 \mathrm{~cm}$ in length and $0.71 \pm 0.1 \mathrm{~g}$.

The shoots were pre-acclimated for seven days in the exposure vessels to prevent biochemical changes resulting from this preparation. Five shoots were used for each treatment and control, and both length and fresh weight of plants were measured from the second day over a period of 32 days. The increase in biomass as fresh weight and the length of the shoots were expressed as a percentage, compared to those at the start of experiments. Additionally, the number of new shoots was counted during the experiment.

\subsection{Statistical Analysis}

The data were statistically assessed on SPSS software (IBM SPSS Statistics, Version 20; New York, NY, USA). Normality of the data sets was tested by Shapiro-Wilk and the homogeneity by Levene's test. Statistical significance between the exposure concentrations and the corresponding controls was identified via one-way ANOVA followed by Tukey's post-hoc at a significance level (alpha) of 0.05. If the data sets failed normality and homogeneity, non-parametric Levene's test was employed. Then, significant differences between treatments and controls were established by the non-parametric Kruskal-Wallis test followed by non-parametric Post-hoc comparisons. Data sets on the concentration of CYN in exposure media and carotenoids to total chlorophyll ratio were analyzed using parametric ANOVA tests followed by Tukey's post-hoc. Data sets corresponding to the enzymatic activity of CAT and GR, contents of chlorophyll $a$ and carotenoids were compared using both parametric (ANOVA) and non-parametric (Kruskal-Wallis) tests. For the statistical analysis of free CYN in tissue, the enzymatic activity of POD and GST, contents of chlorophyll $b$, total chlorophyll, and chlorophyll $a$ to chlorophyll $b$ ratio the non-parametric test Kruskal-Wallis were used. Growth parameters were analyzed by T-test comparing control and each treatment (toxin concentration) for each exposure time at an alpha of 0.05 (where $p<0.05$ represents statistical significance).

\section{Results}

\subsection{CYN Uptake}

No traces of CYN contamination could be detected in the negative control plants, i.e., macrophytes, which were cultivated in Provisoli's void of CYN to test for pre-contamination. In the positive control media, $29.8 \%$ of the CYN had broken down after $24 \mathrm{~h}$, which increased to $37 \%$ after $336 \mathrm{~h}$ (Figure 2A). 

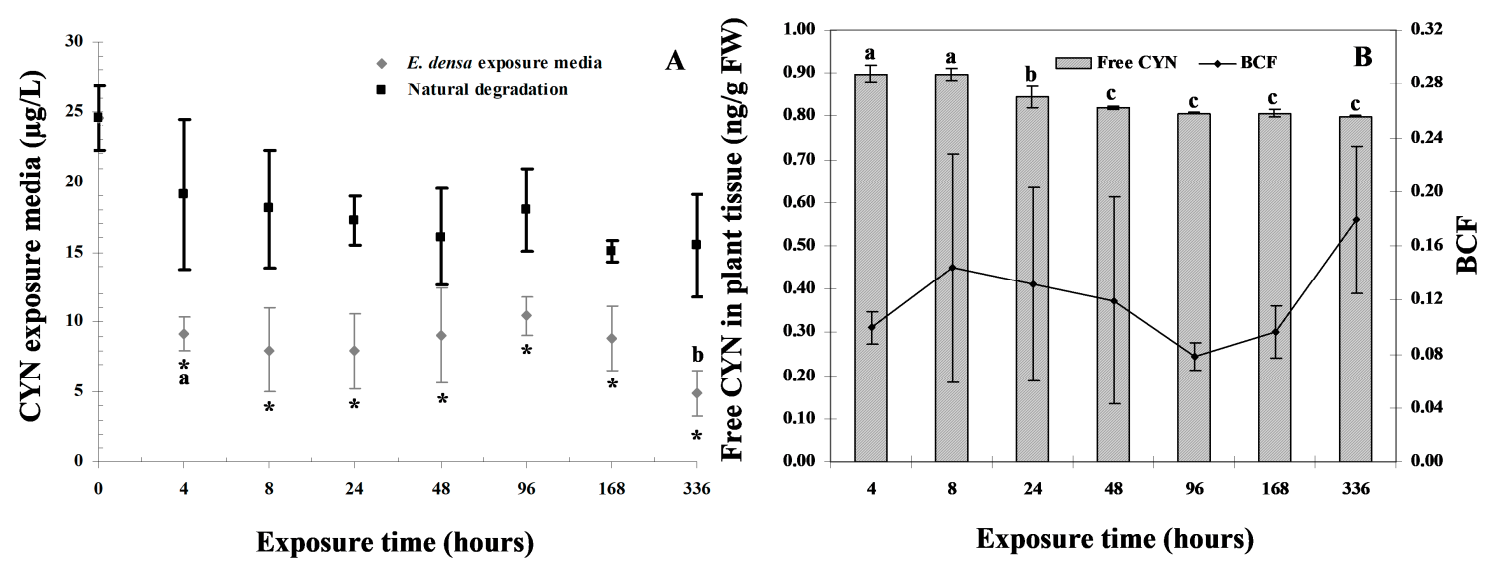

Figure 2. (A) The concentration of dissolved CYN in the exposure media in the presence $(\bullet$ Egeria densa in exposure media containing $25 \mu \mathrm{g} / \mathrm{L} \mathrm{CYN}$; treatment) and absence ( $\boldsymbol{\square}$ Natural degradation; positive control) of E. densa with time. (B) CYN concentration taken up by E. densa with time and corresponding bioconcentration factors $(\mathrm{BCFs})$. Data represent the mean value \pm standard deviation $(n=4)$. Significances compared to the media control are indicated by the asterisks $\left({ }^{*} p<0.05\right)$. Different letters indicate differences at the level of $p<0.05$ of CYN in media (A) and free CYN in the plant biomass (B) by comparing the exposure times.

In the treatments, i.e., exposure media inclosing plants, the CYN concentration was significantly reduced compared to the positive control over the entire exposure period $(p<0.05)$ (Figure 2A). The CYN concentration in the media containing plants decreased after $4 \mathrm{~h}$ from $24.53 \pm 2.32 \mu \mathrm{g} / \mathrm{L}$ to $9.15 \pm 1.17 \mu \mathrm{g} / \mathrm{L}$ equating to $62.70 \% \mathrm{CYN}$ lost. The media CYN concentration continued to decrease within the first $24 \mathrm{~h}$ to $7.91 \pm 2.71 \mu \mathrm{g} / \mathrm{L}(p<0.05)$ (Figure $2 \mathrm{~A})$, equating to a removal percentage of $67.8 \%$. Considering the natural degradation percentage observed, the percentage of CYN removed by E. densa in one day ( $24 \mathrm{~h}$ ) was $54 \%$. After 48,96 , and $168 \mathrm{~h}$, the treatment media CYN concentrations remained significantly lower in relation to the control $(p<0.05)$. However, comparing $8,24,48,96$ and $168 \mathrm{~h}$, the CYN removal percentages by E. densa remained unchanged $(p>0.05)$. The lowest CYN concentration in the exposure media with plants occurred after $336 \mathrm{~h}(4.94 \pm 1.63 \mu \mathrm{g} / \mathrm{L})$ and differed significantly with the CYN concentration at $4 \mathrm{~h}(p<0.05)$. At the end of the experiment (after $336 \mathrm{~h}$ ), up to $80 \%$ of the CYN was removed, of which $68 \%$ corresponded to CYN removal by E. densa only. The CYN removal rate after $4 \mathrm{~h}$, which was $9.62 \mathrm{ng} / \mathrm{min}$, was the highest measured during the study, followed by $5.17 \mathrm{ng} / \mathrm{min}$ after $8 \mathrm{~h}$, while after 48,96 , and $168 \mathrm{~h}$, further uptake was not evidenced with CYN removal rates less than $1 \mathrm{ng} / \mathrm{min}$. Although uptake continued to occur after $336 \mathrm{~h}$, the rate of CYN removal was $0.15 \mathrm{ng} / \mathrm{min}$.

Soluble CYN was found present in the plant biomass at all time point tested ranging from $0.799 \pm 0.002 \mathrm{ng} / \mathrm{g}$ FW to $0.899 \pm 0.019 \mathrm{ng} / \mathrm{g}$ FW (Figure 2B). Free CYN in the plant biomass showed significant dissimilarities between the different exposure times $(p<0.05)$. After 4 and $8 \mathrm{~h}$, free CYN in plant tissues were similar but differed from the plant tissues at 24 and $48 \mathrm{~h}(p<0.05)$, which also tended to decrease. After 96, 168, and $336 \mathrm{~h}$, free CYN in the plant tissues remained similar. The bioconcentration factors (BCF), which was estimated by dividing CYN in the plant tissue (ng/g FW) by CYN in the corresponding water media $(\mathrm{ng} / \mathrm{mL}$ ) for each exposure time, (Figure $2 \mathrm{~B}$ ) ranged from $0.079 \pm 0.010$ $(96 \mathrm{~h})$ to $0.179 \pm 0.054(336 \mathrm{~h})$. However, BCF values were not found to be statistically significant $(p>0.05)$.

Considering the residual CYN in the media after the exposures with $E$. densa, the amount of free CYN detected in the whole plant biomass represented between $0.05 \%$ to $0.08 \%$ of the total amount of CYN removed from the exposure medium. 


\subsection{Hydrogen Peroxide $\left(\mathrm{H}_{2} \mathrm{O}_{2}\right)$}

A significant increase in the intracellular $\mathrm{H}_{2} \mathrm{O}_{2}$ level after $24 \mathrm{~h}$ of exposure was only detected in treatments exposed to $25 \mu \mathrm{g} / \mathrm{L} \mathrm{CYN}$ (Figure 3A) $(p<0.05)$; which was 1.27 times greater than the control. Prior increases of $\mathrm{H}_{2} \mathrm{O}_{2}$ were also observed after $4 \mathrm{~h}$ with exposure to $2.5 \mu \mathrm{g} / \mathrm{L}$ (1.22 times) and $25 \mu \mathrm{g} / \mathrm{L}$ (1.24 times) CYN, but both values did not differ between them $(p=1)$. After $96 \mathrm{~h}$, only the level of $\mathrm{H}_{2} \mathrm{O}_{2}$ in the treatment with $25 \mu \mathrm{g} / \mathrm{L} \mathrm{CYN}$ increased significantly (1.43 times) compared to the control $(p<0.05)$. A further significant increase of $\mathrm{H}_{2} \mathrm{O}_{2}$ occurred after $336 \mathrm{~h}$ only at $25 \mu \mathrm{g} / \mathrm{L} \mathrm{CYN}$, which was 1.37 times higher than the control $(p<0.05)$ (Figure 3B).
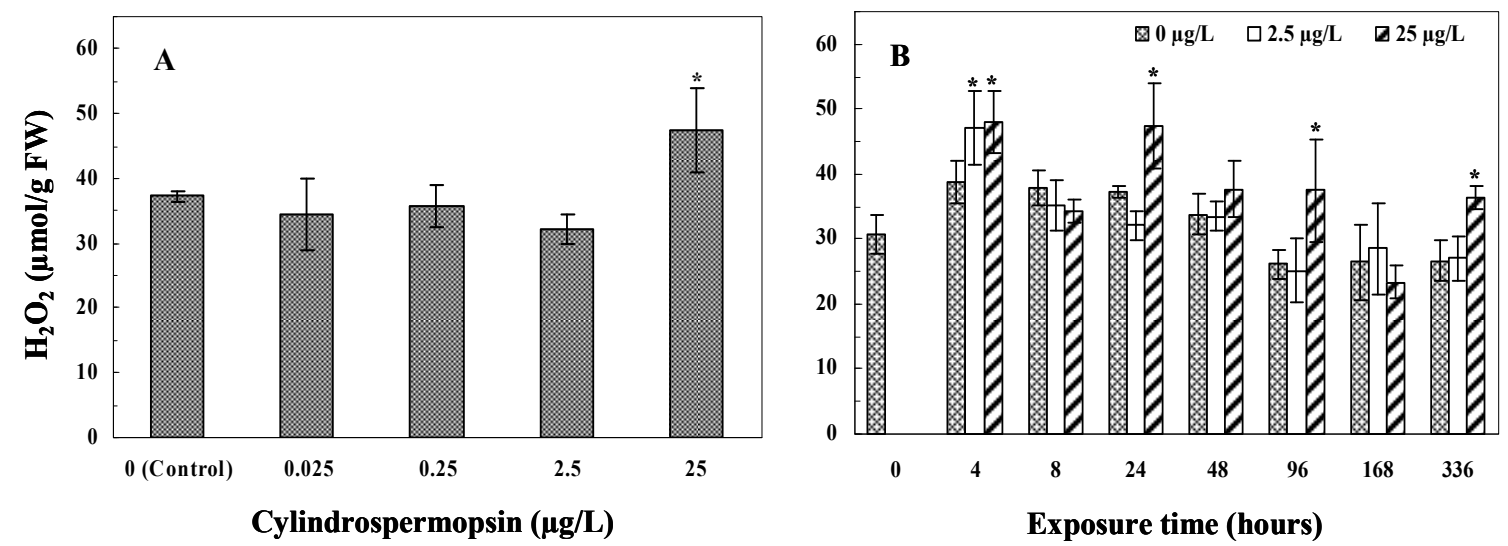

Figure 3. Levels of $\mathrm{H}_{2} \mathrm{O}_{2}$ in E. densa (A) with exposure to four concentrations of CYN for $24 \mathrm{~h}$ and (B) after exposures with time to $2.5 \mu \mathrm{g} / \mathrm{L}$ and $25 \mu \mathrm{g} / \mathrm{L} \mathrm{CYN}$. Data represent mean $\mathrm{H}_{2} \mathrm{O}_{2}$ concentration \pm standard deviation of five independent samples, each determined two times $(n=5)$. Significance compared to the control is shown by an asterisk $\left.{ }^{*} p<0.05\right)$.

\subsection{Enzyme Activity}

\subsubsection{CAT Activity}

After $24 \mathrm{~h}$ of exposure, the CAT activity increased significantly in the $0.25,2.5$, and $25 \mu \mathrm{g} / \mathrm{L}$ CYN treatments compared to control $(p<0.05)$; activities with exposure to $0.25 \mu \mathrm{g} / \mathrm{L}$ and $2.5 \mu \mathrm{g} / \mathrm{L}$ differed from $25 \mu \mathrm{g} / \mathrm{L}(p<0.05)$. The maximum activity for CAT corresponded with the highest CYN concentration after $24 \mathrm{~h}$ ( 2.89 times) (Figure $4 \mathrm{~A}$ ). From the first hours of exposure up to the end of the experiment, CAT activity was mainly higher with exposure to the highest concentration, i.e., $25 \mu \mathrm{g} / \mathrm{L}$ (Figure 4B). After $4 \mathrm{~h}, \mathrm{CAT}$ activity at $25 \mu \mathrm{g} / \mathrm{L} \mathrm{CYN}$ was also higher than that of the corresponding control $(p<0.05)$, meanwhile after $8 \mathrm{~h}$ the highest activity of CAT corresponded to exposure with $2.5 \mu \mathrm{g} / \mathrm{L} \mathrm{CYN}(p<0.05)$. After $48 \mathrm{~h}$, CAT activity at $2.5 \mu \mathrm{g} / \mathrm{L}(1.52$ times $)$ and $25 \mu \mathrm{g} / \mathrm{L}(1.58$ times $)$ diminished but remained higher than the corresponding controls $(p<0.05)$, followed by increases after $96 \mathrm{~h}(p<0.05)$. Here CAT showed the second highest activity at $25 \mu \mathrm{g} / \mathrm{L} \mathrm{CYN}(2.64$ times). Within $168 \mathrm{~h}$ and $336 \mathrm{~h}, \mathrm{CAT}$ activities at $2.5 \mu \mathrm{g} / \mathrm{L}$ (1.96 times and 1.81 times respectively) and $25 \mu \mathrm{g} / \mathrm{L}$ ( 2.45 times and 2.38 times respectively) remained higher compared to the respective control $(p<0.05)$ but tended to decrease (at $2.5 \mu \mathrm{g} / \mathrm{L}$ ) or stayed similarly (at $25 \mu \mathrm{g} / \mathrm{L}$ ). 

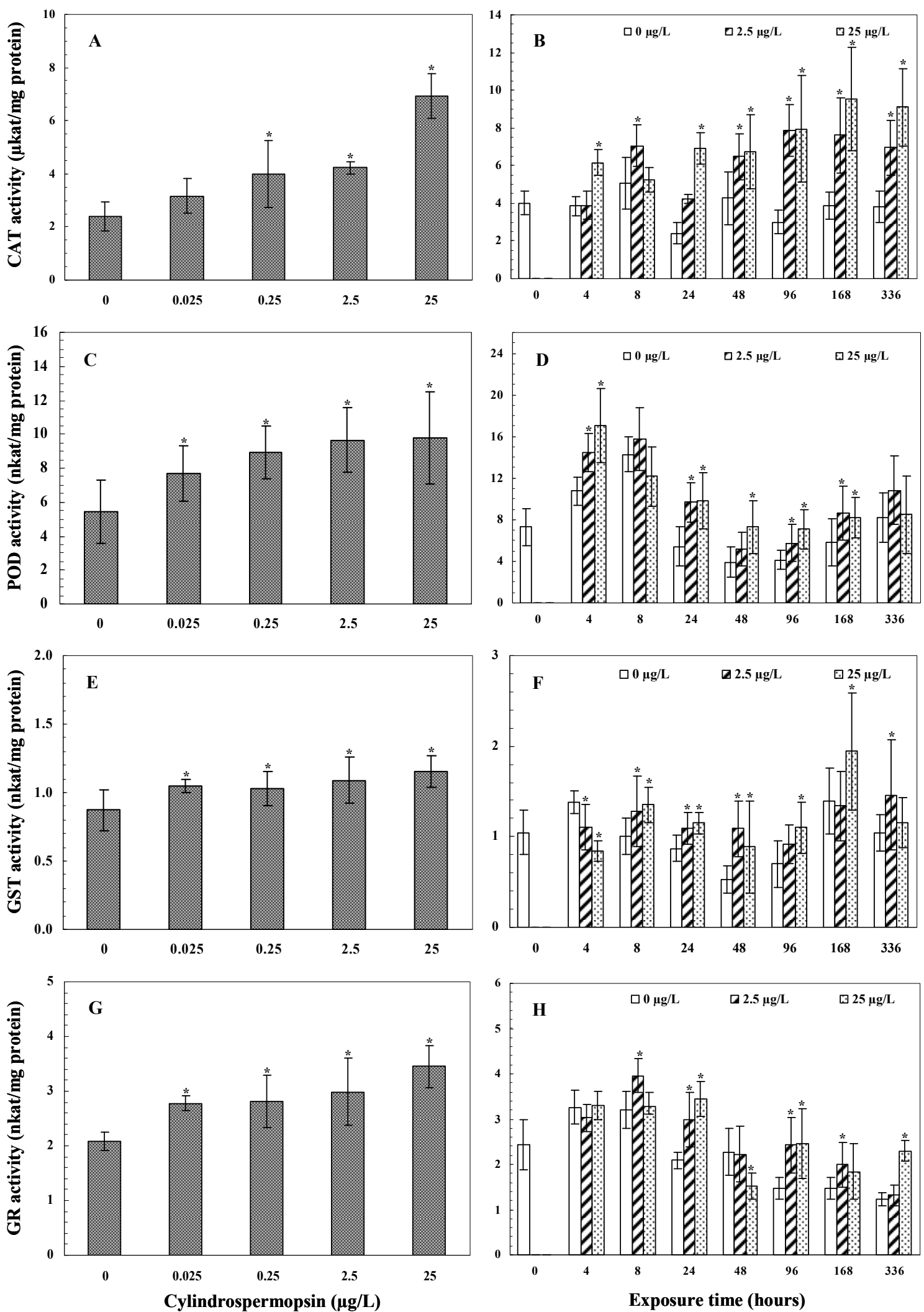

Figure 4. The (A) CAT, (C) POD, (E) GST, and (G) GR activities in E. densa after exposure to four concentrations of CYN for $24 \mathrm{~h}$. The (B) CAT, (D) POD, (F) GST, and (H) GR activities in E. densa with CYN exposures at 2.5 and $25 \mu \mathrm{g} / \mathrm{L}$ for $336 \mathrm{~h}$. Data represent the means \pm standard deviation of five independent samples $(n=5)$, each determined three times. Significance compared to the control is shown by an asterisk $(* p<0.05)$. 


\subsubsection{POD Activity}

The activity of POD showed significant increases with all four exposure concentrations after $24 \mathrm{~h}$ compared to the control $(p<0.05)$, but no differences were found among them $(p>0.05)$ (Figure $4 \mathrm{C})$. After $4 \mathrm{~h}$ of exposure, POD activity increased significantly with exposure to $2.5 \mu \mathrm{g} / \mathrm{L}$ (1.34 times) and $25 \mu \mathrm{g} / \mathrm{L}$ (1.58 times) compared to the control $(p<0.05)$ (Figure 4D). The highest POD activity occurred after $48 \mathrm{~h}$ of exposure at $25 \mu \mathrm{g} / \mathrm{L}$ and was 1.87-fold higher than that of the control $(p<0.05)$. Within $96 \mathrm{~h}$ and $168 \mathrm{~h}, \mathrm{POD}$ activity showed significant differences with $2.5 \mu \mathrm{g} / \mathrm{L}$ and $25 \mu \mathrm{g} / \mathrm{L}$ CYN compared to the corresponding control $(p<0.05)$ but remained similar between them for both exposure times. POD activity also tended to decrease slightly in this time interval, remaining similar to the control after $336 \mathrm{~h}(p>0.05)$.

\subsubsection{GST Activity}

A significant enhancement $(p<0.05)$ of GST activity was found in plants treated with all four CYN concentrations after $24 \mathrm{~h}$ but differences between them were not showed $(p>0.05)$ (Figure $4 \mathrm{E}$ ). After the first $4 \mathrm{~h}$ of exposure, GST activity decreased significantly with $2.5 \mu \mathrm{g} / \mathrm{L}$ and $25 \mu \mathrm{g} / \mathrm{L} \mathrm{CYN}$ compared to the control $(p<0.05)$ (Figure $4 \mathrm{~F})$. However, the GST activity increased significantly for both CYN concentrations after $8 \mathrm{~h}$ and until $48 \mathrm{~h}$ of exposure $(p<0.05)$. The maximum GST activity was reported after $48 \mathrm{~h}$ and corresponded to $2.5 \mu \mathrm{g} / \mathrm{L}$ ( 2.06 times) followed by 1.68 times to $25 \mu \mathrm{g} / \mathrm{L}$ at the same time exposure. After 96 and $168 \mathrm{~h}$, further significant increases in the GST activity were observed only with $25 \mu \mathrm{g} / \mathrm{L} \mathrm{CYN}$ exposure, which were respectively 1.58 times and 1.39 times higher than the corresponding controls $(p<0.05)$. After $336 \mathrm{~h}$, GST activity increased significantly only at $2.5 \mu \mathrm{g} / \mathrm{L} \mathrm{CYN}(1.40$ times) compared to the corresponding control $(p<0.05)$.

\subsubsection{GR Activity}

The GR activity increased significantly for all four CYN concentrations after $24 \mathrm{~h}(p<0.05)$ (Figure 4G). Only GR activities at $0.025 \mu \mathrm{g} / \mathrm{L}$ and $0.25 \mu \mathrm{g} / \mathrm{L}$ differed from GR activity at $25 \mu \mathrm{g} / \mathrm{L}$ $(p<0.05)$. Activities of GR at $2.5 \mu \mathrm{g} / \mathrm{L}$ after $8,24,96$, and $168 \mathrm{~h}$ were significantly increased compared to the control $(p<0.05)$ (Figure $4 \mathrm{H})$. The GR activity at $25 \mu \mathrm{g} / \mathrm{L}$ showed significant enhancements $(p<0.05)$ after 24,96 , and $336 \mathrm{~h}$ showing the maximum GR activity $(1.86$ times) after $336 \mathrm{~h}$. The GR activity after $48 \mathrm{~h}$ at $25 \mu \mathrm{g} / \mathrm{L} \mathrm{CYN}$ showed a significant decrease compared to the control $(p<0.05)$.

\subsection{Photosynthetic Pigment Contents}

The chlorophyll $a$, chlorophyll $b$, total chlorophyll, and carotenoid content in E. densa reacted similarly after $24 \mathrm{~h}$ with decreases observed only with $25 \mu \mathrm{g} / \mathrm{L}$ CYN exposure compared to the respective control $(p<0.05)$ (Figure 5A,C,E,G). Further decreases of pigment contents with $25 \mu \mathrm{g} / \mathrm{L}$ CYN concentration were seen at $48 \mathrm{~h}(p<0.05)$ (Figure 5B,D,F,H); however, these returned to the same concentrations as the corresponding control within $96 \mathrm{~h}(p>0.05)$. Only the carotenoids showed an increase after $96 \mathrm{~h}$ compared to the corresponding control $(p<0.05)$ (Figure 5H). Decreases of pigment contents were again seen after $168 \mathrm{~h}(p<0.05)$, which then returned to the normal stated compared to the control $(p>0.05)$ until $336 \mathrm{~h}$. With exposure to $2.5 \mu \mathrm{g} / \mathrm{L} \mathrm{CYN}$, the chlorophyll $a$, chlorophyll $b$, total chlorophyll, and carotenoid contents showed significant decreases after $48 \mathrm{~h}$. Chlorophyll $b$ and total chlorophyll returned to the same concentrations as the control within $96 \mathrm{~h}$ and $336 \mathrm{~h}$ (Figure 5D,F). Chlorophyll $a$ with $2.5 \mu \mathrm{g} / \mathrm{L}$ CYN showed a further decrease after $96 \mathrm{~h}$, followed by normalization within $168 \mathrm{~h}$ and $336 \mathrm{~h}$ (Figure 5B). Likewise, carotenoids decreased again $(p<0.05)$ but later $(168 \mathrm{~h})$, returning to the same concentration as the control after $336 \mathrm{~h}$ (Figure $5 \mathrm{H})$. 

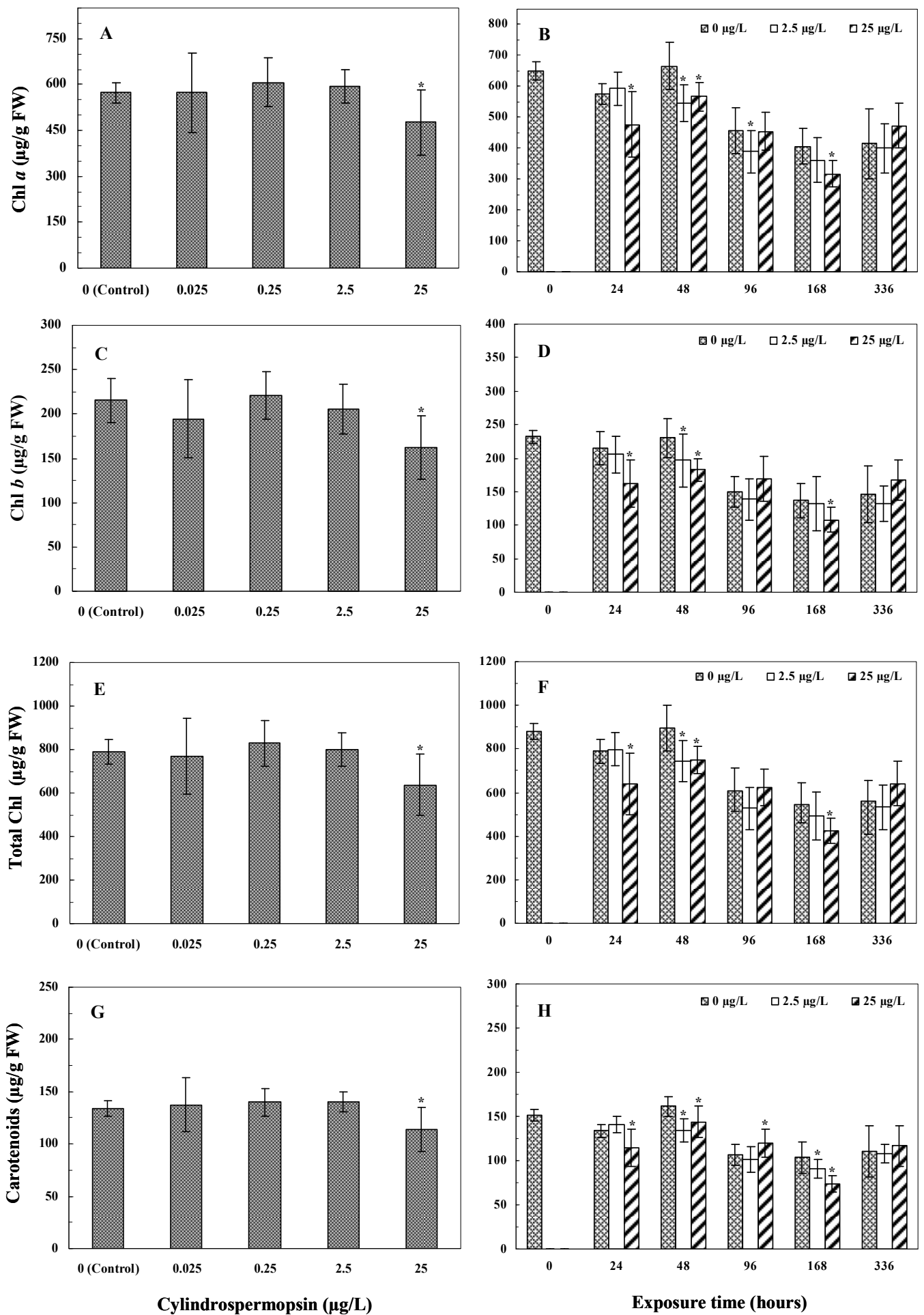

Figure 5. The (A) chlorophyll $a,(\mathbf{C})$ chlorophyll $b$, (E) total chlorophyll, and (G) carotenoid content in E. densa exposed to four CYN concentrations for $24 \mathrm{~h}$ and (B) chlorophyll $a,(\mathbf{D})$ chlorophyll $b,(\mathbf{F})$ total chlorophyll, and (H) carotenoid content exposed to $2.5 \mu \mathrm{g} / \mathrm{L}$ and $25 \mu \mathrm{g} / \mathrm{L} \mathrm{CYN}$ for $336 \mathrm{~h}$. The data represent average pigment concentration \pm standard deviation of five independent samples $(n=5)$, each determined three times. Significance compared to the control is shown by an asterisk $\left({ }^{*} p<0.05\right)$.

The ratio of chlorophyll $a$ to chlorophyll $b$ increased significantly with exposure to $2.5 \mu \mathrm{g} / \mathrm{L}$ and $25 \mu \mathrm{g} / \mathrm{L}$ after $24 \mathrm{~h}(p<0.05)$ (Figure 6A,B). After $48 \mathrm{~h}$ with $2.5 \mu \mathrm{g} / \mathrm{L} \mathrm{CYN}$, chlorophyll $a$ to chlorophyll $b$ ratio returned to similar ratios as the control, thus remaining until $336 \mathrm{~h}$ exposure (Figure $6 \mathrm{~A}$ ). 
With $25 \mu \mathrm{g} / \mathrm{L} \mathrm{CYN}$ exposure, the chlorophyll $a$ to $b$ ratio continued to increase after $48 \mathrm{~h}(p<0.05)$ and returned to the same ratios as the control within $96 \mathrm{~h}$ and $336 \mathrm{~h}(p>0.05)$ (Figure $6 \mathrm{~B})$. The carotenoids to total chlorophyll ratio only increased significantly compared to the control after $96 \mathrm{~h}$ with both $2.5 \mu \mathrm{g} / \mathrm{L}$ and $25 \mu \mathrm{g} / \mathrm{L} \mathrm{CYN}$ exposure $(p<0.05)$ (Figure 6C,D).
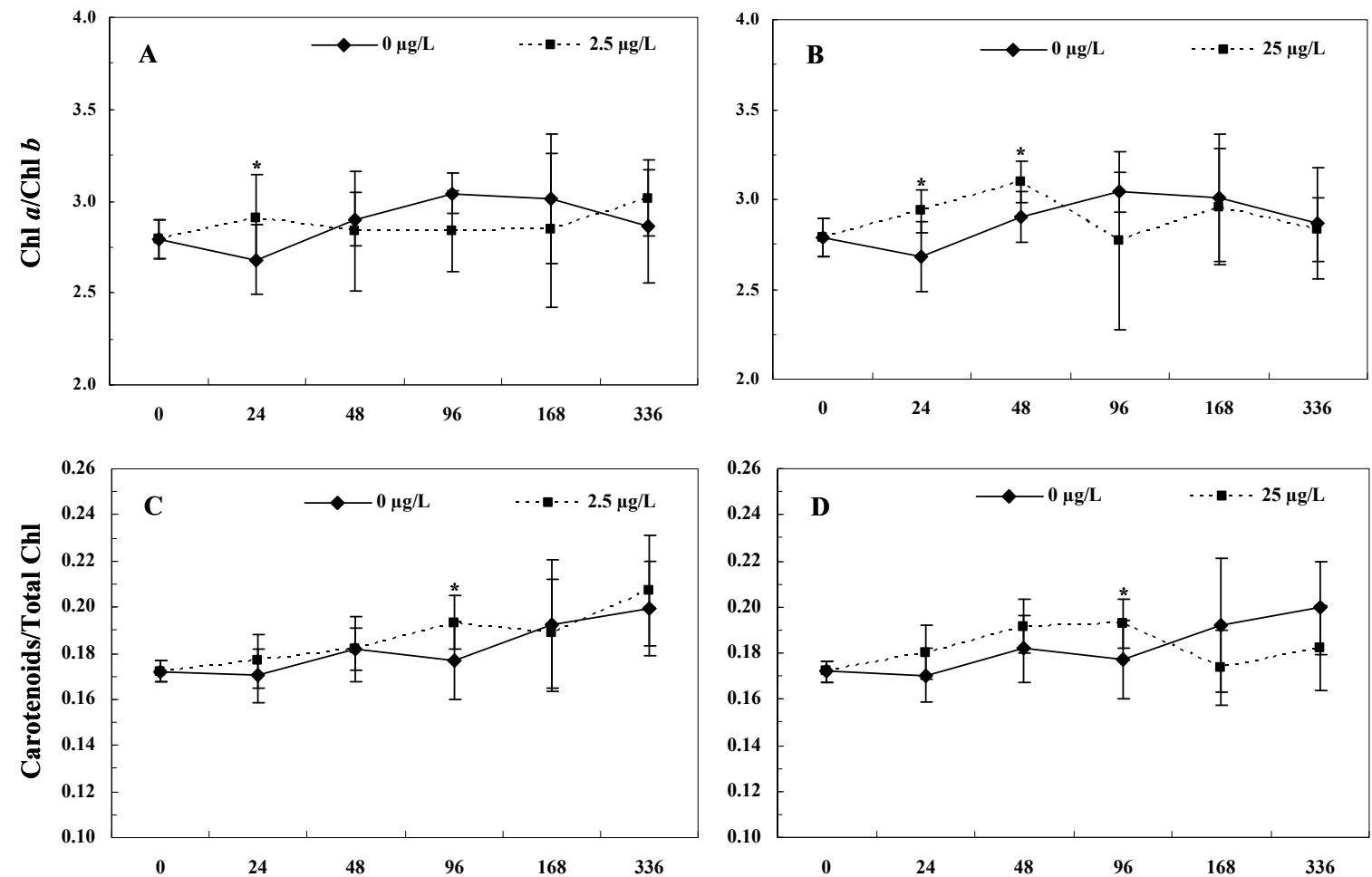

Exposure Time (hours)

Figure 6. The ratio of chlorophyll $a$ to $b$ in E. densa exposed to (A) $2.5 \mu \mathrm{g} / \mathrm{L}$ and (B) $25 \mu \mathrm{g} / \mathrm{L} \mathrm{CYN}$ as well as the ratio of carotenoids to total chlorophyll with exposure to (C) $2.5 \mu \mathrm{g} / \mathrm{L}$ and (D) $25 \mu \mathrm{g} / \mathrm{L} \mathrm{CYN}$. Significance compared to the control is shown by an asterisk $\left({ }^{*} p<0.05\right)$.

\subsection{Plant Growth}

\subsubsection{Changes in Fresh Weight}

E. densa treated with CYN showed an increase in fresh weight within the first two days for all four exposure concentrations used ( $p<0.05)$, of which increases with exposure to $2.5 \mu \mathrm{g} / \mathrm{L} \mathrm{CYN}$, followed by $25 \mu \mathrm{g} / \mathrm{L}$, were most prominent (Figure 7A,B,C,D). At $0.025 \mu \mathrm{g} / \mathrm{L} \mathrm{CYN}$, plants started to show mild inhibitory effects after four days, following by 11 and 14 days $(p<0.05)$ (Figure 7A). Stagnation in the increase of fresh weight was seen after 21 days, but the decrease only was significant after 32 days $(p<0.05)$. Plants exposed to $0.25 \mu \mathrm{g} / \mathrm{L} \mathrm{CYN} \mathrm{did} \mathrm{not} \mathrm{show} \mathrm{statistically} \mathrm{significant} \mathrm{decreases} \mathrm{of} \mathrm{fresh}$ weight within 14 days ( $p>0.05$ ), but the decrease of fresh weight became significant within 28 and 32 days $(p<0.05)$ (Figure 7B). With exposure to $2.5 \mu \mathrm{g} / \mathrm{L}$, E. densa showed a significant decrease in fresh weight after 32 days $(p<0.05)$ (Figure $7 \mathrm{C}$ ). While with $25 \mu \mathrm{g} / \mathrm{L} \mathrm{CYN}$, stagnation followed by significant decreases of fresh weight occurred after 14 days and continued until day $32(p<0.05)$ (Figure 7D). 


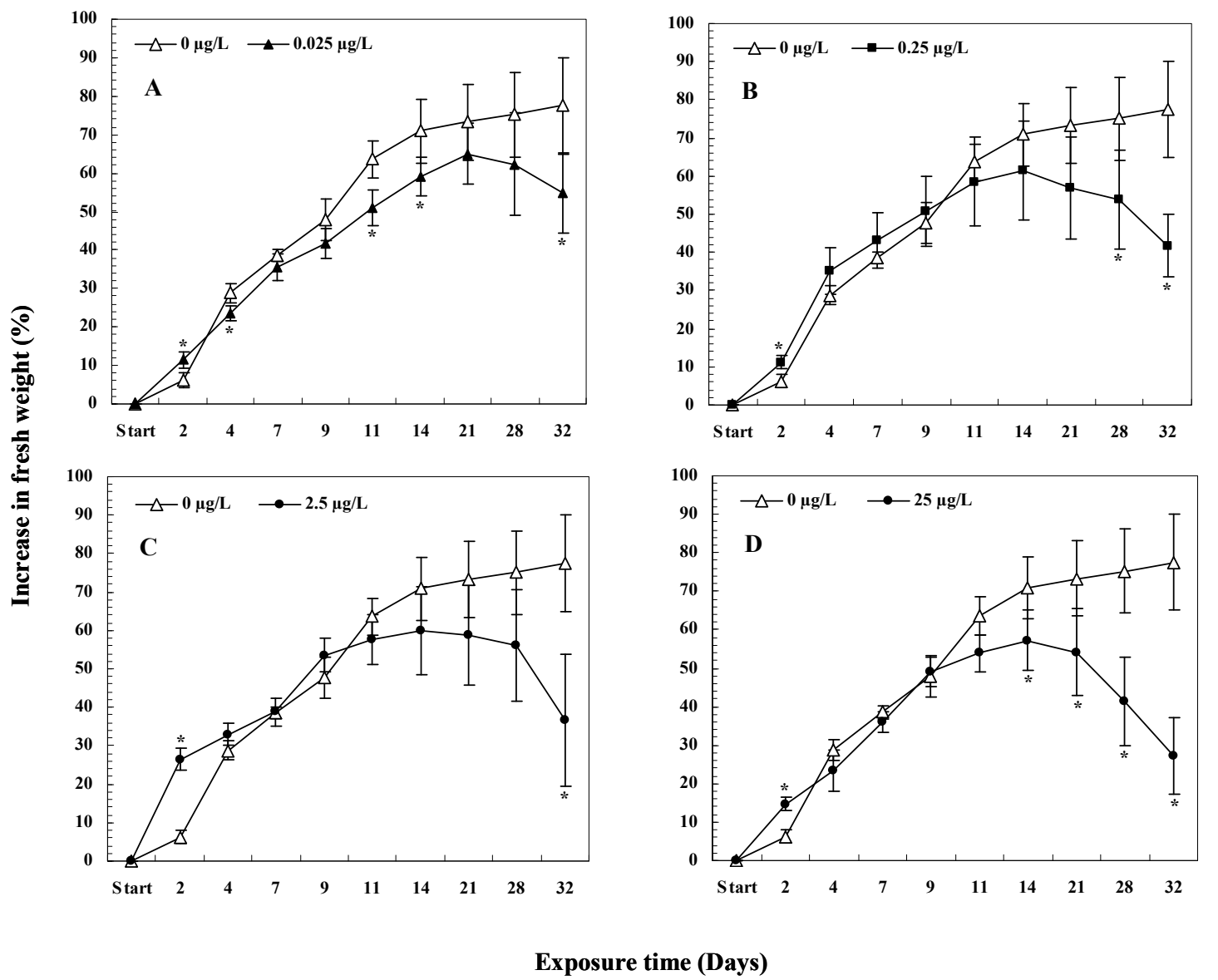

Figure 7. The growth of E. densa denoted as the average percentage increase of fresh weight $(n=5)$ \pm standard deviation as a function of (A) $0.025 \mu \mathrm{g} / \mathrm{L},(\mathbf{B}) 0.25 \mu \mathrm{g} / \mathrm{L},(\mathbf{C}) 2.5 \mu \mathrm{g} / \mathrm{L}$, and (D) $25 \mu \mathrm{g} / \mathrm{L} \mathrm{CYN}$ exposure. Significance compared to the control is shown by an asterisk $\left({ }^{*} p<0.05\right)$.

\subsubsection{Changes in Plant Lengths and New Shoots}

E. densa shoots exposed to $0.025 \mu \mathrm{g} / \mathrm{L}$ and $0.25 \mu \mathrm{g} / \mathrm{L} \mathrm{CYN}$, in general, did not show changes in plant lengths (Figure 8A,B). Increases of shoot length were seen in plants exposed to $2.5 \mu \mathrm{g} / \mathrm{L}$ and $25 \mu \mathrm{g} / \mathrm{L}$ CYN (Figure 8C,D), which were significant at $2.5 \mu \mathrm{g} / \mathrm{L}$ within two days and seven days (Figure $8 \mathrm{C}$ ); likewise, increases with $25 \mu \mathrm{g} / \mathrm{L}$ CYN exposure were seen after seven days and 11 days $(p<0.05)$ (Figure 8D). The stagnation of shoot length growth was seen after 14 days, for which the inhibitory was significant only after 14 days with $25 \mu \mathrm{g} / \mathrm{L} \mathrm{CYN}$ and 32 days with both $2.5 \mu \mathrm{g} / \mathrm{L}$ and $25 \mu \mathrm{g} / \mathrm{L} \mathrm{CYN}$ concentrations $(p<0.05)$.

The appearance of new shoots in E. densa differed according to the CYN concentrations. With exposure to $0.025 \mu \mathrm{g} / \mathrm{L} \mathrm{CYN}$, new shoots appeared after two days, followed by seven days, but this was less than compared to the control $(p<0.05)$ (Figure 8E). Within seven days and 14 days, the number of new shoots between days did not vary but were less compared to the control $(p<0.05)$. After 21 days, the new shoots reached a similar number compared to the control, and this remained so until day $32(p>0.05)$. The number of new shoots that developed albeit exposure to $0.25 \mu \mathrm{g} / \mathrm{L}$ was similar compared to those seen developing in the control $(p>0.05)$ with an increase only after 28 days. At $2.5 \mu \mathrm{g} / \mathrm{L} \mathrm{CYN}$, the amount of new shoots was below that observed in the controls and showed significant differences within nine days and 21 days, followed by 32 days $(p<0.05)$. The total number of shoots remained similar between day nine and day 32. At $25 \mu \mathrm{g} / \mathrm{L}$, new shoots appeared later, i.e., after seven days, reaching the maximum amount after 11 days and remained unchanged until day 32. The number of new shoots during the 32-days exposure was always below that of the controls $(p<0.05)$. 

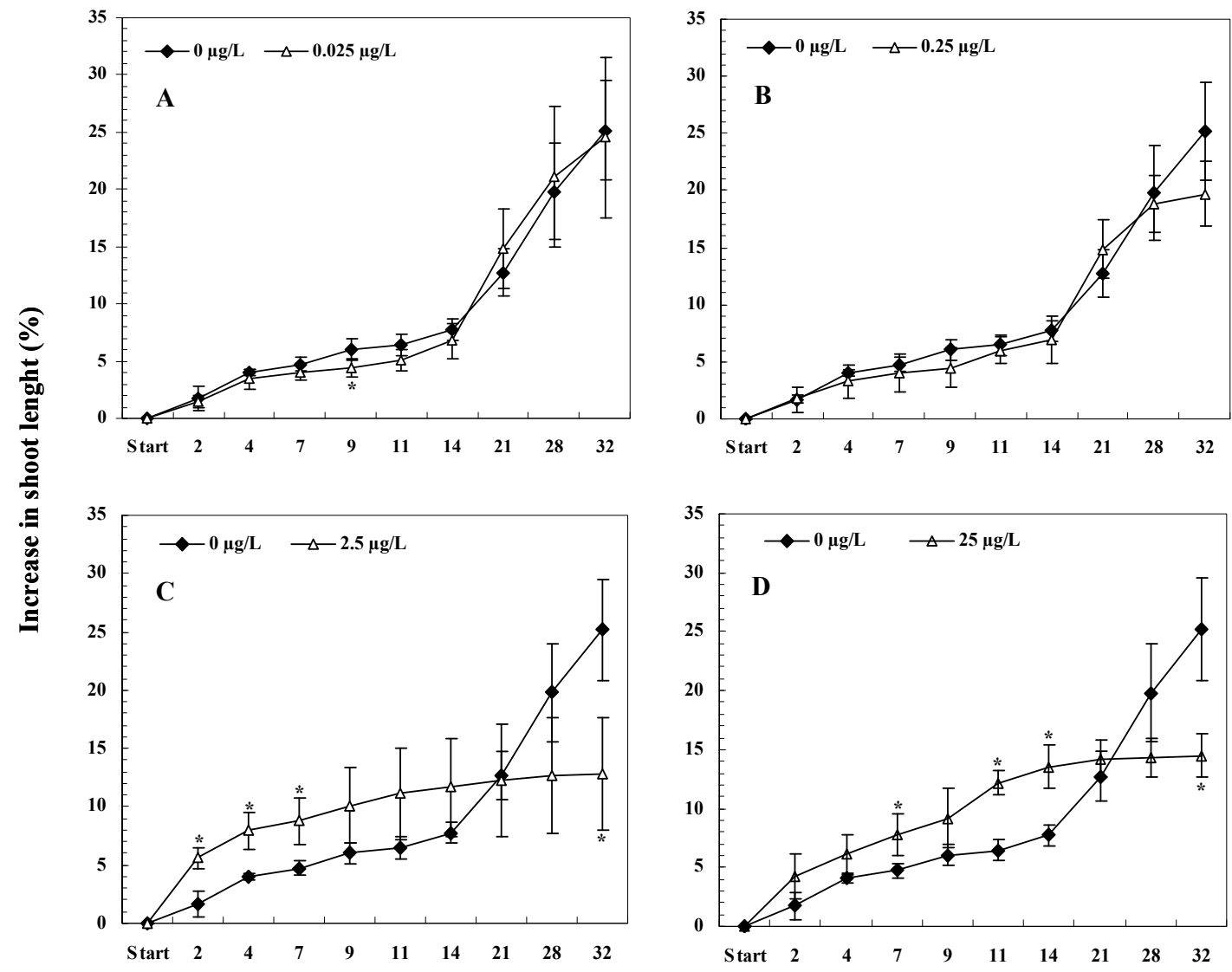

Exposure time (Days)

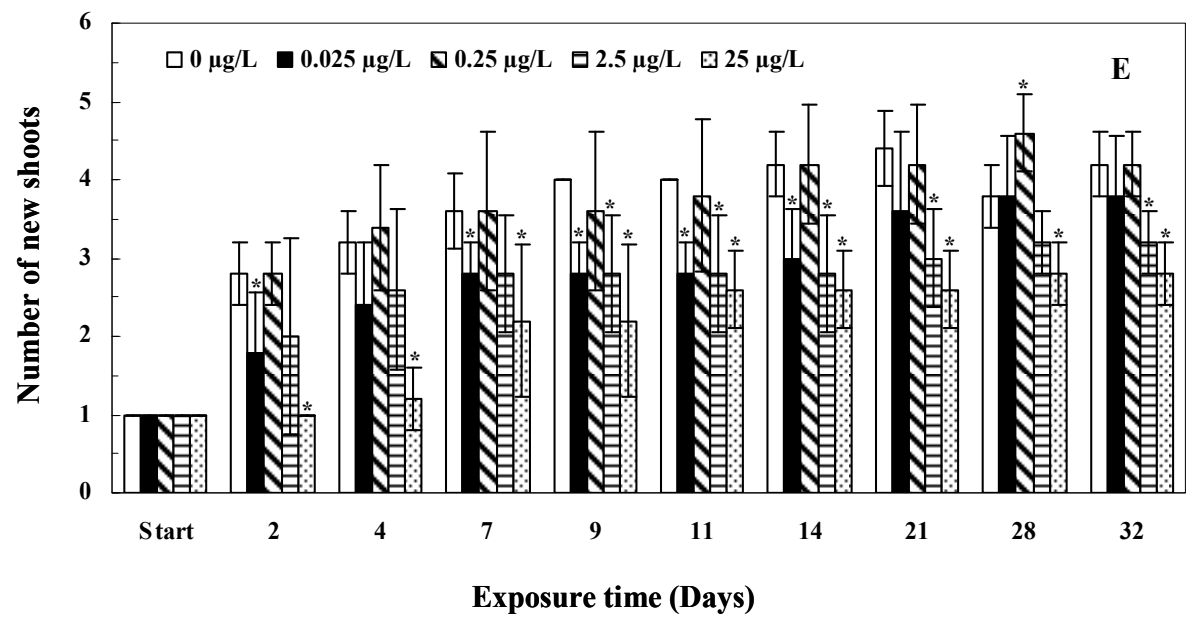

Figure 8. The growth of $E$. densa as the mean percentage increase in shoot length $(n=5)$ with exposure to (A) $0.025 \mu \mathrm{g} / \mathrm{L},($ B) $0.25 \mu \mathrm{g} / \mathrm{L}$, (C) $2.5 \mu \mathrm{g} / \mathrm{L}$, and (D) $25 \mu \mathrm{g} / \mathrm{L} \mathrm{CYN}$, as well as the mean number of new shoots with exposure to the four CYN concentrations (E). Significance compared to the control is shown by an asterisk ( $\left.{ }^{*} p<0.05\right)$.

\section{Discussion}

The lowered CYN concentrations in the exposures compared to the positive controls, which lacked plants, together with rapid removal of CYN within the first $4 \mathrm{~h}$ of exposure, confirmed that even though natural degradation occurred [8], E. densa was responsible for more than $50 \%$ of the toxin removal observed, which reached up to $65 \%$ at the end of the experiment. The results indicate that this 
macrophyte is more efficient than L. minor [15], which reached a CYN removal percentage of $43 \%$ after $24 \mathrm{~h}$ of treatment with the same CYN concentration and experimental conditions [15]. The findings also suggest that E. densa adsorbed CYN most efficiently at the start of the exposure, concurring with previous studies on CYN uptake in macrophytes [12,15] as well as other cyanotoxins [38-41]. The rapid partial toxin removal suggests that CYN adhesion could occur on the cell wall due to its zwitterionic properties [4]. It is important to mention that after CYN uptake within the first hours, further uptake of CYN continues until $336 \mathrm{~h}$. There is an interval time ( $48 \mathrm{~h}-168 \mathrm{~h}$ ), in which the CYN concentrations in the exposure media remained similar, suggesting that the uptake is substantially slowed after $24 \mathrm{~h}$. In this interval, changes in the metabolism of E. densa were promoted by CYN, tending to stabilize within $168 \mathrm{~h}$ as evidenced by alterations of the antioxidant enzyme activity and the concentrations of photosynthetic pigments. Whether the structure of CYN is modified or metabolized in plant cells as the plant continues to take up CYN, is an unanswered question and requires further investigations. The low amounts of free CYN detected in plant tissue, which decreased between 24 and $48 \mathrm{~h}$, and then remained unchanged from 96 to $336 \mathrm{~h}$, suggest that internalized CYN could be enzymatically attached, altered or metabolized within the plant cells averting detection [12]. A study which exposed different animal and plant proteins to CYN revealed that the proteins extracts and concentrations influenced the soluble CYN detectable. However, the study reported that when incubating CYN with amino acids and oxidized or reduced glutathione, all of the added toxin remained soluble proposing protein binding as a reason the CYN being undetectable previously [42]. The low $\mathrm{BCF}$ indicating no bioaccumulation $(\mathrm{BCF}<1)$ reported here agree with earlier studies related to $C Y N$ exposure at higher and similar concentrations [12-15]. Here, E. densa exposed to $25 \mu \mathrm{g} / \mathrm{L} \mathrm{CYN} \mathrm{took}$ up $0.065 \% \pm 0.015 \%$ per exposure organism, which is similar to uptake reported for the same species exposed to $50 \mu \mathrm{g} / \mathrm{L}$ [26]. Thes values are lower compared to the percentage of CYN per exposure organism (0.30\%) reported in L. minor [15]. The low concentration of CYN remaining in the media and the amounts of free CYN in E. densa also support the possibility that the cyanotoxin could be adhering to plant cells components. However, the former studies, together with the data currently presented, do not confirm the association of CYN to proteins and need further investigation.

In general, CAT, POD, GST, and GR activity did not increase dose-dependently after $24 \mathrm{~h}$ of exposure to $\mathrm{CYN}$. Increased $\mathrm{H}_{2} \mathrm{O}_{2}$ levels with time coincided with the increased CAT and POD activities at 2.5 and $25 \mu \mathrm{g} / \mathrm{L} \mathrm{CYN}$. While CAT and POD activities correlated with CYN removal within 4 hours and $24 \mathrm{~h}$, further increases of them can be linked with changes in the content of photosynthetic pigments and growth parameters as plant response to CYN exposure. The maintenance of high activities mainly of CAT during the experiment can be explained by the further CYN uptake at $336 \mathrm{~h}$ by E. densa.

Although $\mathrm{H}_{2} \mathrm{O}_{2}$ is involved in a range of biochemical reactions and signaling cascades necessary plant growth and is a constant byproduct of normal metabolism [43], excessive $\mathrm{H}_{2} \mathrm{O}_{2}$ needs to be eliminated from the cells. $\mathrm{H}_{2} \mathrm{O}_{2}$ is mainly formed in chloroplasts and mitochondria during electron transfer [43]. This study shows that concentrations of $2.5 \mu \mathrm{g} / \mathrm{L}$ and $25 \mu \mathrm{g} / \mathrm{L} \mathrm{CYN} \mathrm{promote} \mathrm{high} \mathrm{CAT}$ activities within $336 \mathrm{~h}$, which is a link to the high levels of $\mathrm{H}_{2} \mathrm{O}_{2}$ within $336 \mathrm{~h}$ mainly at the highest CYN concentration. From the results, it can be inferred that this defense mechanism remains active against oxidative stress in which CAT plays a major role. Equivalent observations were obtained in a previous study with L. minor, in which CAT activity increased in treatments with 2.5 and $25 \mu \mathrm{g} / \mathrm{L} \mathrm{CYN} \mathrm{within}$ $168 \mathrm{~h}$ [18]. CAT, as a member of the superoxide dismutase (SOD) system, acts as the first defense against oxygen toxicity [44]. SOD dismutates $\mathrm{O}_{2}{ }^{-}$to molecular oxygen and $\mathrm{H}_{2} \mathrm{O}_{2}$, which is reclaimed by CAT $[45,46]$. Studies about CYN effects on SOD system are scarce, but it has been demonstrated that the activity of CAT and SOD are induced in aquatic plants by exposure to heavy metals [45,47]. In addition, in E. densa exposed to MCs, the activity of CAT and SOD increased after two days of exposure [22]. The levels of $\mathrm{H}_{2} \mathrm{O}_{2}$ remaining unchanged compared to the control after 48 and $168 \mathrm{~h}$ are explained by the enhancements of POD activity at the same time. POD is involved in phenolic metabolism expending $\mathrm{H}_{2} \mathrm{O}_{2}$ as substrate and plays an important role in the biosynthesis of lignin and how plants respond to pathogens [43]. This study shows high POD activities within $168 \mathrm{~h}$, which together with 
CAT can maintain $\mathrm{H}_{2} \mathrm{O}_{2}$ levels similar to control after 48 and $168 \mathrm{~h}$. Flores-Rojas et al. [18] found that in L. minor exposed to CYN $(0.025-25 \mu \mathrm{g} / \mathrm{L})$, the activity of POD was not significantly promoted. In contrast to Lemna sp. [48], E. densa has higher percentages of lignin in stems and forms roots along its stems [49], which can transport nutrients and control homeostasis. Since E. densa is a submerged macrophyte, it is more exposed to CYN than the floating macrophyte L. minor, inducing more ROS production, which leads the antioxidative activation of POD and CAT.

GST and GR in E. densa tended to remain active after 24 and $168 \mathrm{~h}$. An interesting result after $4 \mathrm{~h}$ of exposure to 2.5 and $25 \mu \mathrm{g} / \mathrm{L} \mathrm{CYN}$ is lowered GST activity, accompanied by GR activity similar to control. This scenario suggests that GST is activated before $4 \mathrm{~h}$ as a response against acute stress, followed by an imbalance between GSH/GSSG [50]. The remaining activity of GR in the first hours can prove the recovery of GSH [50]. Both enzymes tend to maintain high activities between 24 and $96 \mathrm{~h}$ at the highest CYN concentration. Notably is the lower activity of GR together with higher GST activity after $48 \mathrm{~h}$ with $25 \mu \mathrm{g} / \mathrm{L}$ CYN. This indicates other imbalance between GSH/GSSG, in which enhancement of GSH can occur because of changes in the growth and concentration of photosynthetic pigments as strategies to stress tolerance [51]. Further high activities of GST and GR at $96 \mathrm{~h}$ tend to diminish the generation of ROS.

The outcomes of CYN exposure on the chlorophyll $a$ and $b$ contents presented in previous studies have been contradictory [14,20]. In L. minor, increased chlorophyll $a$ and carotenoids concentrations resulted within $24 \mathrm{~h}$ at CYN concentrations under $25 \mu \mathrm{g} / \mathrm{L}$ [15]. A. filiculoides exposed to CYN experienced increased carotenoid levels [14]. In the current study, decreased chlorophyll $a$, chlorophyll $b$, total chlorophyll, and carotenoids contents were observed after $24 \mathrm{~h}$ mainly at $25 \mathrm{~g} / \mathrm{L} \mathrm{CYN}$, which can be linked with higher $\mathrm{H}_{2} \mathrm{O}_{2}$ concentrations and higher activities of antioxidative enzymes. The slower metabolism of photosynthetic pigments, which also involves the production of $\mathrm{H}_{2} \mathrm{O}_{2}$ [43], could be a strategy to counteract the high levels of $\mathrm{H}_{2} \mathrm{O}_{2}$. This scenario remains after $48 \mathrm{~h}$ with a tendency to stabilize the chlorophyll $a$ to chlorophyll $b$ ratios. Subsequent stabilization of chlorophyll $a$ and chlorophyll $b$ levels, accompanied by enhancements of carotenoids and ratios of carotenoids to total chlorophyll at $96 \mathrm{~h}$ with $25 \mu \mathrm{g} / \mathrm{L} \mathrm{CYN} \mathrm{may} \mathrm{be} \mathrm{vital} \mathrm{for} \mathrm{maintaining} \mathrm{the} \mathrm{complex} \mathrm{chlorophyll-carotenoid}$ binding proteins, which are needed to absorb and convert light energy during photosynthesis. The increased carotenoids levels after $96 \mathrm{~h}$ also suggest their activity in the antioxidative system response to combat excessive ROS formation promoted by CYN [52]. Subsequent decreases of the photosynthetic pigment levels but accompanied by balanced ratios of chlorophyll $a$ to chlorophyll $b$ and carotenoids to total chlorophyll after $168 \mathrm{~h}$ showed the stabilization of photosynthetic system in E. densa toward the end of the experiment. Changes at $2.5 \mu \mathrm{g} / \mathrm{L} \mathrm{CYN}$ also show stabilization of photosynthetic system but in a shorter time.

Regarding the growth response, in two studies pertaining to L. punctata and H. verticillata [13,20], the relative growth was stimulated with exposure to CYN. In A. filiculoides, the increased growth in the presence of CYN was ascribed as being a defense strategy [14]. For L. minor exposed to $25 \mu \mathrm{g} / \mathrm{L}$ CYN, Flores-Rojas et al. [15] reported an increase in the number of fronds, below that of the control, which normalized after 14 days. Increased fresh weight in E. densa within the first two days, even at lower CYN concentrations, accompanied by a tendency to increase the shoot length in plants exposed to 2.5 and $25 \mu \mathrm{g} / \mathrm{L} \mathrm{CYN}$ within the first 11 days, can be a strategy to combat toxicity. Growth also produces enhancements of ROS and the subsequent increased antioxidative enzymatic activity. Fresh weight gain within the first two days coincided with increased antioxidative enzymatic activities even to lower CYN concentrations (after $24 \mathrm{~h}$ ) and changes in photosynthetic pigments levels mainly noted in plants exposed to 2.5 and $25 \mu \mathrm{g} / \mathrm{L} \mathrm{CYN}$. The subsequent fresh weight stabilization between 4 and 14 days, accompanied by the stimulation of shoot length within 11 days could be a reaction to maintain the balance of homeostatic processes in the plant. Additionally, decreases of the photosynthetic pigment levels maintaining their ratios after $336 \mathrm{~h}$ show a strategy to balance ROS, which is also generating by shoot length stimulation. After $336 \mathrm{~h}$ (14 days), E. densa reacted against CYN uptake again, as evident by the changes observed in growth parameters. Although decreases in fresh weight 
were more evident within 28 and 32 days at 2.5 and $25 \mu \mathrm{g} / \mathrm{L} \mathrm{CYN}$, the stagnation after 14 days and decreases of shoot length until the end of the 32-days exposure seem to be a better indicator of changes due to the further CYN uptake after $336 \mathrm{~h}$. The delayed appearance of new shoots with exposure to $25 \mu \mathrm{g} / \mathrm{L}$ CYN can indicate inhibition caused by CYN but at the same time a response toward ROS imbalance. Remarkably, chlorosis was observed during the experiment, which occurred after 14 days mainly in plants exposed to $25 \mu \mathrm{g} / \mathrm{L}$; however, they remained alive during the 32-days exposure and forming small new leaves. Reduced plant vitality and biomass production can result from damage or inhibited biosynthesis of the photosynthetic pigments [53]. Although the photosynthetic system in E. densa tended to balance within $336 \mathrm{~h}$, appearance of chlorosis in some shoots and not so robust plants after 14 days and until 32-days exposure can confirm the alteration of this. Changes in the morphological pattern of development in plants are one of the acclimation strategies in response to environmental stresses [51,53], which together with the biochemical and physiological responses can be mechanisms of resistance to CYN in E. densa within the fourteen first days. However, this study cannot confirm how long this aquatic plant maintains the regulation of its metabolism after a subsequent CYN uptake because this depends on the plant condition, CYN remaining concentration and exposure time. In aquatic ecosystems, high concentrations of CYN can be found even after months of an algal bloom [3], thus increasing the risk of affecting the macrophyte communities. The monitoring of biomarkers as CAT, carotenoids, and the ratios of chlorophyll $a$ to chlorophyll $b$ and carotenoids to total chlorophyll can elucidate the metabolism regulation and health condition of macrophytes.

\section{Conclusions}

In the presented study, CYN exposure at environmental concentrations did not cause bioaccumulation of the toxin in E. densa. The antioxidative enzymatic system remained active during the whole exposure period of $336 \mathrm{~h}$ with exposure to both 2.5 and $25 \mu \mathrm{g} / \mathrm{L} \mathrm{CYN}$ exposure. In response to $\mathrm{CYN}$ exposure, the pigment concentrations decreased, but the ratios of chl $a / b$ and carotenoids/total chl elevated for a short period tending to balance, probably to combat the adverse effects of the xenobiotic. The increase in the carotenoid content after $96 \mathrm{~h}$ suggests the intervention of these in the antioxidant system. These results indicate that E. densa can tolerate CYN toxicity. Moreover, stimulation of the fresh weight at the short time and shoot length within the first 14 days with 2.5 and $25 \mu \mathrm{g} / \mathrm{L}$ CYN support this evidence. However, this study also showed stagnation and inhibition after 14 days, and this could respond to the CYN uptake by E. densa after $336 \mathrm{~h}$ exposure. Although E. densa seems to be unaffected and even capable of combat adverse effects linked to CYN exposure for $336 \mathrm{~h}$, it is necessary to investigate the responses of aquatic macrophytes to long exposures in order to elucidate the stagnation and inhibition growth and the possibility of plant health recovery. While the bioaccumulation of CYN was not found, the remotion of this toxin by E. densa over $65 \%$ and its moderate tolerance within 14 days apparently without lethal effects, open the possibility to consider E. densa as a candidate for sustainable phytoremediation, but CYN uptake needs further investigations. Even though the removal percentage exhibited by E. densa would not likely result to remediation of CYN in the environment to under the accepted guideline value of $1 \mu \mathrm{g} / \mathrm{L}$, the macrophyte could contribute in a phytoremediation system comprising of several species, such as in the case of the Green Liver System, to form a comprehensive CYN remediation solution. According to the results, E. densa also showed changes in appearance and biomass due to exposure to CYN. In aquatic environments, these morphological changes can affect the communities of macrophytes depending on CYN concentrations and time of exposure. This study confirms that exposures to concentrations of $2.5 \mu \mathrm{g} / \mathrm{L} \mathrm{CYN}$ and greater can be harmful to biota. The biochemical and physiological responses contribute to the understanding of the morphological changes and uptake abilities. In addition, measures of antioxidative enzymes and photosynthetic pigments can be used as biomarkers of plant health. Further studies with more macrophytes can make it possible to develop additional tools to control CYN in aquatic environments. E. densa proved to be sensitive to CYN exposure with apparent biochemical and morphological responses, but its use as bioindicator needs additional investigation, 
particularly in mesocosm experiments. These experiments must be carried out taking into account the physical and chemical parameter changes in water and sediment, the light conditions, and the relationship between macrophyte species, e.g., using floating emergent and submerged macrophytes, simulating a natural environment under controlled conditions.

Author Contributions: Conceptualization, N.C.F.-R. and M.E.; methodology, N.C.F.-R.; validation, M.E.; formal analysis, N.C.F.-R.; investigation, N.C.F.-R.; resources, M.E.; data curation, N.C.F.-R.; writing-original draft preparation, N.C.F.-R.; writing—review and editing, M.E.; supervision, M.E.; project administration, M.E.; funding acquisition, M.E. All authors have read and agreed to the published version of the manuscript.

Funding: This research received no external funding.

Acknowledgments: The authors thank Stephan Pflugmacher for the support during the conceptualization and Sandra Kühn for technical assistance in the laboratory. Administrative and technical support provided by Technische Universität Berlin. Open access funding provided by the University of Helsinki.

Conflicts of Interest: The authors declare no conflict of interest.

\section{References}

1. De la Cruz, A.; Hiskia, A.; Kaulodis, T.; Chernoff, N.; Hill, D.; Antoniou, M.; He, X.; Loftin, K.; O'Shea, K.; Zhao, C.; et al. A review on cylindrospermopsin: The global occurrence, detection, toxicity and degradation of a potent cyanotoxin. Environ. Sci. Process. Impacts 2013, 15, 1979-2003. [CrossRef] [PubMed]

2. B-Béres, V.; Vasas, G.; Dobronoki, D.; Gonda, S.; Nagy, S.A.; Bàcsi, I. Effects of Cylindrospermopsin Producing Cyanobacterium and Its Crude Extracts on a Benthic Green Alga-Compertition or Allelopathy? Mar. Drugs 2015, 13, 6703-6722. [CrossRef] [PubMed]

3. Kinnear, S. Cylindrospermopsin: A decade of progress on bioaccumulation research. Mar. Drugs 2010, 8, 542-564. [CrossRef] [PubMed]

4. Ohtani, I.; Moore, R.E.; Runnegar, M.T.C. Cylindrospermopsin: A potent hepatotoxin from the blue-green alga. J. Am. Chem. Soc. 1992, 114, 7941-7942. [CrossRef]

5. Banker, R.; Carmeli, S.; Teltsch, B.; Sukenik, A. 7-Epicylindrospermopsin, a toxic minor metabolite of the cyanobacterium Aphanizomenon ovalisporum from Lake Kinneret, Israel. J. Nat. Prod. 2000, 63, 387-389. [CrossRef]

6. Norris, R.L.; Eaglesham, G.; Pierens, G.; Shaw, G.; Smith, M.J.; Chiswell, R.K.; Seawright, A.A.; Moore, M.R. Deoxycylindrospermopsin, an analog of cylindrospermopsin from Cylindrospermopsis raciborskii. Environ. Toxicol. 1999, 14, 163-165. [CrossRef]

7. Wörmer, L.; Huerta-Fontela, M.; Cirés, S.; Quesada, A. Natural photodegradation of the cyanobacterial toxins microcystin and cylindrospermopsin. Environ. Sci. Technol. 2010, 44, 3002-3007. [CrossRef]

8. Chiswell, R.K.; Shaw, G.R.; Eaglesham, G.; Smith, M.J.; Norris, R.L.; Seawright, A.A.; Moore, M.R. Stability of cylindrospermopsin, the toxin from the cyanobacterium, Cylindrospermopsis raciborskii: Effect of $\mathrm{pH}$, temperature, and sunlight on decomposition. Environ. Toxicol. 1999, 14, 155-161. [CrossRef]

9. Guzmán-Guillén, R.; Prieto, A.I.; Vasconcelos, V.M.; Cameán, A.M. Cyanobacterium producing cylindrospermopsin cause oxidative stress at environmentally relevant concentrations in sub-chronically exposed tilapia (Oreochromis niloticus). Chemosphere 2013, 90, 1184-1194. [CrossRef]

10. Moreira, C.; Azevedo, J.; Antunes, A.; Vasconcelos, V. Cylindrospermopsin: Occurrence, methods of detection and toxicology. J. Appl. Microbiol. 2012, 114, 605-620. [CrossRef]

11. Thomaz, S.M.; da Cunha, E.R. The role of macrophytes in habitat structuring in aquatic ecosystems: Methods of measurement, causes and consequences on animal assemblages' composition and biodiversity. Acta Limnol. Bras. 2010, 22, 218-236. [CrossRef]

12. White, S.H.; Duivenvoorden, L.J.; Fabbro, L.D. Absence of free-cylindrospermopsin bioconcentration in Water Thyme (Hydrilla verticillata). Bull. Environ. Contam. Toxicol. 2005, 75, 574-583. [CrossRef]

13. Kinnear, S.H.W.; Duivenvoorden, L.J.; Fabbro, L.D. Growth and bioconcentration in Spirodella oligorrhiza following exposure to Cylindrospermopsis raciborskii whole-cell extracts. Australas. J. Ecotoxicol. 2007, 13, 19-31.

14. Santos, C.; Azevedo, J.; Campos, A.; Vasconcelos, V.; Pereira, A. Biochemical and growth performance of the aquatic macrophyte Azolla filiculoides to sub-chronic exposure to cylindrospermopsin. Ecotoxicology 2015, 24, 1848-1857. [CrossRef] [PubMed] 
15. Flores-Rojas, N.C.; Esterhuizen-Londt, M.; Plugmacher, S. Uptake, Growth, and Pigment Changes in Lemna minor L. exposed to Environmental Concentrations of Cylindrospermopsin. Toxins 2019, 11, 650. [CrossRef] [PubMed]

16. Prieto, A.; Campos, A.; Camea, A.; Vasconcelos, V. Effects on growth and oxidative stress status of rice plants (Oryza sativa) exposed to two extracts of toxin-producing cyanobacteria (Aphanizomenon ovalisporum and Microcystis aeruginosa). Ecotoxicol. Environ. Saf. 2011, 74, 1973-1980. [CrossRef] [PubMed]

17. Freitas, M.; Azevedo, J.; Pinto, E.; Neves, J.; Campos, A.; Vasconcelos, V. Effects of microcystin-LR, cylindrospermopsin and a microcystin-LR/cylindrospermopsin mixture on growth, oxidative stress and mineral content in lettuce plants (Lactuca sativa L.). Ecotoxicol. Environ. Saf. 2015, 116, 59-67. [CrossRef] [PubMed]

18. Flores-Rojas, N.C.; Esterhuizen-Londt, M.; Pflugmacher, S. Antioxidative stress responses in the floating macrophyte Lemna minor L. with cylindrospermopsin exposure. Aquat. Toxicol. 2015, 169, 188-195. [CrossRef] [PubMed]

19. Jámbrik, K.; Máthé, C.; Vasas, G.; Bácsi, I.; Surányi, G.; Gonda, S.; Borbély, G.; M-Hamvas, M. Cylindrospermopsin inhibits growth and modulates protease activity in the aquatic plants Lemna minor $\mathrm{L}$. and Wolffia arrhiza (L.) Horkel. Acta Biol. Hung. 2010, 61, 77-94. [CrossRef]

20. Kinnear, S.H.W.; Fabbro, L.D.; Duivenvoorden, L.J. Variable growth responses of water thyme (Hydrilla verticillata) to whole-cell extracts of Cylindrospermopsis raciborskii. Arch. Environ. Contam. Toxicol. 2008, 54, 187-194. [CrossRef]

21. Pflugmacher, S.; Kühn, S.; Lee, S.-H.; Choi, J.-W.; Baik, S.; Kwon, K.-S.; Contardo-Jara, V. Green Liver Systems ${ }^{\circledR}$ for water purification: Using the phytoremediation potential of aquatic macrophytes for the removal of different cyanobacterial toxins from water. Am. J. Plant Sci. 2015, 6, 1607-1618. [CrossRef]

22. Amorim, C.A.; Ulisses, C.; Moura, A.N. Biometric and physiological responses of Egeria densa Planch. cultivated with toxic and non-toxic strains of Microcystis. Aquat. Toxicol. 2017, 191, 201-208. [CrossRef] [PubMed]

23. Romero-Oliva, C.S.; Contardo-Jara, V.; Pflugmacher, S. Antioxidative response of the three macrophytes Ceratophyllum demersum, Egeria densa, and Hydrilla verticillata to a time-dependent exposure of cell-free crude extracts containing three microcystins from cyanobacterial blooms of Lake Amatitlán, Guatemala. Aquat. Toxicol. 2015, 163, 130-139. [CrossRef]

24. Rücker, J.; Stüken, A.; Nixdorf, B.; Fastner, J.; Chorus, I.; Wiedner, C. Concentrations of particulate and dissolved cylindrospermopsin in 21 Aphanizomenon-dominated temperate lakes. Toxicon 2007, 50, 800-809. [CrossRef]

25. Corbel, S.; Mougin, C.; Bouaïcha, N. Cyanobacterial toxins: Modes of actions, fate in aquatic and soil ecosystems, phytotoxicity and bioaccumulation in agricultural crops. Chemosphere 2014, 96, 1-15. [CrossRef] [PubMed]

26. Esterhuizen-Londt, M.; Kühn, S.; Pflugmacher, S. Development and validation of an in-house quantitative analysis method for cylindrospermopsin using hydrophilic interaction liquid chromatography-tandem mass spectrometry: Quantification demonstrated in 4 aquatic organisms. Environ. Toxicol. Chem. 2015, 34, 2878-2883. [CrossRef]

27. Arnot, J.A.; Gobas, F.A.P.C. A review of bioconcentration factor (BCF) and bioaccumulation factor (BAF) assessments for organic chemicals in aquatics organisms. Environ. Rev. 2006, 14, 257-297. [CrossRef]

28. Jana, S.; Choudhuri, M.A. Glycolate metabolism of three submerged aquatic angiosperms during aging. Aquat. Bot. 1982, 12, 345-354. [CrossRef]

29. Pflugmacher, S. Promotion of oxidative stress in the aquatic macrophyte Ceratophyllum demersum during biotransformation of the cyanobacterial toxin microcystin-LR. Aquat. Toxicol. 2004, 70, 169-178. [CrossRef]

30. Bradford, M. A rapid and sensitive method for the quantification of microgram quantities of protein utilizing the principle of protein-dye binding. Anal. Biochem. 1976, 72, 248-254. [CrossRef]

31. Claiborne, A. Catalase activity. In CRC Handbook of Methods for Oxygen Radical Research; Greenwald, R.A., Ed.; CRC Press: Boca Raton, FL, USA, 1985; pp. 283-284.

32. Pütter, J. Peroxidases. In Methods of Enzymatic Analysis; Bergmeyer, H.U., Ed.; Academic Press: New York, NY, USA, 1974; Volume 2, pp. 685-690.

33. Habig, W.; Pabst, M.J.; Jacoby, W.B. Glutathione S-transferase: The first step in mercapturic acid formation. J. Biol. Chem. 1974, 249, 1730-1739. 
34. Carlberg, I.; Mannervik, B. Glutathione reductase. Methods Enzymol. 1985, 113, 484-490.

35. Inskeep, W.P.; Bloom, P.R. Extinction coefficients of chlorophyll $a$ and $b$ in N, N-Dimethylformamide and 80\% acetone. Plant Physiol. 1985, 77, 483-485. [CrossRef] [PubMed]

36. Wellburn, A.R. The spectral determination of chlorophyll $a$ and chlorophyll $b$, as well as total carotenoids, using various solvents with spectrophotometers of different resolution. J. Plant Physiol. 1994, 144, 307-313. [CrossRef]

37. Ashraf, M.; Harris, P.J.C. Photosynthesis under stressful environments: An overview. Photosynthetica 2013, 51, 163-190. [CrossRef]

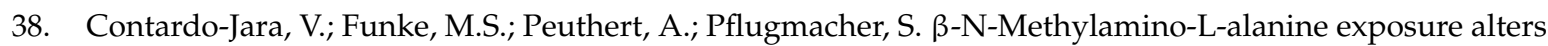
defense against oxidative stress in aquatic plants Lomariopsis lineata, Fontinalis antipyretica, Riccia fluitans and Taxiphyllum barbieri. Ecotoxicol. Environ. Saf. 2013, 88, 72-78. [CrossRef]

39. Nimptsch, J.; Wiegand, C.; Pflugmacher, S. Cyanobacterial toxin elimination via bioaccumulation of MC-LR in aquatic macrophytes: An application of the "Green Liver Concept". Environ. Sci. Technol. 2008, 42, 8552-8557. [CrossRef]

40. Esterhuizen-Londt, M.; Pflugmacher, S.; Downing, T. ß-N-Methylamino-l-alanine (BMAA) uptake by the aquatic macrophyte Ceratophyllum demersum. Ecotoxicol. Environ. Saf. 2011, 74, 74-77. [CrossRef]

41. Ha, M.-H.; Contardo-Jara, V.; Pflugmacher, S. Uptake of the cyanobacterial neurotoxin, anatoxin-a, and alterations in oxidative stress in the submerged aquatic plant Ceratophyllum demersum. Ecotoxicol. Environ. Saf. 2014, 101, 205-212. [CrossRef]

42. Esterhuizen-Londt, M.; Pflugmacher, S. Inability to detect free cylindrospermopsin in spiked aquatic organism extracts plausibly suggests protein binding. Toxicon 2016, 122, 89-93. [CrossRef]

43. Cheeseman, J.M. Hydrogen Peroxide and Plant Stress: A Challenging Relationship. Plant Stress. 2007, 1, 4-15.

44. Mittler, R. Oxidative stress, antioxidants and stress tolerance. Trends Plant Sci. 2002, 7, 405-410. [CrossRef]

45. Malar, S.; Vikram, S.; Favas, P.; Perumal, V. Lead heavy metal toxicity induced changes on growth and antioxidative enzymes level in water hyacinths Eichhornia crassipes (Mart.). Bot. Stud. 2014, 55, 54. [CrossRef] [PubMed]

46. Sharma, P.; Jha, A.B.; Dubey, R.S.; Pessarakli, M. Reactive Oxygen Species, Oxidative Damage, and Antioxidative Defense Mechanism in Plants under Stressful Conditions. J. Bot. 2012, 2012, 217037. [CrossRef]

47. Zhang, H.; Zhang, L.L.; Li, J.; Chen, M.; An, R.D. Comparative study on the bioaccumulation of lead, cadmium and nickel and their toxic effects on the growth and enzyme defence strategies of a heavy metal accumulator, Hydrilla verticillata (L.f.) Royle. Environ. Sci. Pollut. Res. 2020, 27, 9853-9865. [CrossRef]

48. Fang, Y.; Du, A.; Tan, L.; He., K.; Jin, Y.; Tian, X.; Xu, Y.; Zhao, H. Proteomics in Duckweeds. In the Compendium Duckweed Genomes. Compendium of Plant Genomes; Cao, X., Fourounjian, P., Wang, W., Eds.; Springer: Cham, Switzerl; Berlin/Heidelberg, Germany, 2020; pp. 137-141.

49. Hardiningtyas, S.D.; Aziz, F.; Santoso, J.; Uju. Characterization of aquatic plant (Egeria densa) pre-treated by alkaline hydrogen peroxide. IOP Conf. Ser. Earth Environ. Sci. 2019, 404, 1. [CrossRef]

50. Tausz, M.; Sircelj, H.; Grill, D. The glutathione system as a stress marker in plant ecophysiology: Is a stress-response concept valid? J. Exp. Bot. 2004, 55, 1955-1962. [CrossRef]

51. Potters, G.; Pasternak, T.; Guisez, Y.; Palme, K.; Jansen, M. Stress-induced morphogenic responses: Growing out of trouble? Trends Plant Sci. 2007, 12, 98-105. [CrossRef]

52. Zuluaga, M.; Gueguen, V.; Pavon-Djavid, G.; Letourneur, D. Carotenoids from microalgae to block oxidative stress. Bioimpacts 2017, 7, 1-3. [CrossRef]

53. Ha, M.H.; Pflugmacher, S. Time-dependent alterations in growth, photosynthetic pigments and enzymatic defense systems of submerged Ceratophyllum demersum during exposure to the cyanobacterial neurotoxin anatoxin-a. Aquat. Toxicol. 2013, 138-139, 26-34. [CrossRef]

Publisher's Note: MDPI stays neutral with regard to jurisdictional claims in published maps and institutional affiliations. 